\title{
Clay minerals interaction with microorganisms: a review
}

\author{
JAVIER CUADROS* \\ Department of Earth Sciences, Natural History Museum, Cromwell Road, London SW7 5BD, UK
}

(Received 23 January 2017; revised 13 May 2017; Associate Editor: Jeff Wilson)

\begin{abstract}
Interest in mineral-microbe interaction has grown enormously over recent decades, providing information in a puzzle-like manner which points towards an ever increasingly intimate relationship between the two; a relationship that can be truly termed co-evolution. Clay minerals play a very central role in this co-evolving system. Some 20 years ago, clay scientists looked at clay mineralmicrobe studies as a peripheral interest only. Now, can clay scientists think that they understand the formation of clay minerals throughout geological history if they do not include life in their models? The answer is probably no, but we do not yet know the relative weight of biological and inorganic factors involved in driving clay-mineral formation and transformation. Similarly, microbiologists are missing out important information if they do not investigate the influence and modifications that minerals, particularly clay minerals, have on microbial activity and evolution. This review attempts to describe the several points relating clay minerals and microorganisms that have been discovered so far. The information obtained is still very incomplete and many opportunities exist for clay scientists to help to write the real history of the biosphere.
\end{abstract}

KEYWORDS: biogeochemistry, bio-reduction and oxidation, bioweathering, clay biomineralization, Critical Zone, mineral-life co-evolution.

Life has modified our planet in so many and interconnected ways that it is difficult to make a comprehensive list of the main modifications. Even when considering minerals alone the task of generating a synthetic view of their interaction with life is not easy. There are good reasons to focus on microorganisms for the investigation of life-mineral interactions. The first is that it is a very good first approximation of the problem because: (1) microorganisms are by far the most abundant living beings; (2) they have been on Earth much longer than larger life forms; and (3) a great proportion of them live in direct contact with mineral surfaces. It has been estimated that $\sim 50 \%$ of the total biological C corresponds to prokaryotes, of which virtually all live in contact with mineral surfaces

*E-mail: j.cuadros@nhm.ac.uk

https://doi.org/10.1180/claymin.2017.052.2.05
(Whitman et al., 1998). Microfungi, free or in symbiosis with plants and algae, are also very numerous. An estimated $25 \%$ of the entire biological mass is made up of fungi (Miller, 1992), of which microscopic fungi are the largest component. From these numbers it follows that prokaryotes and microfungi are perhaps $\sim 75 \%$ of the biological mass in the planet, of which the majority live in contact with minerals. The proportion of microscopic algae living in contact with minerals needs to be added to this figure. Microscopic algae are extremely abundant, but the number that live on or under mineral surfaces is probably significantly less than that of prokaryotes and fungi. Fungi and algae appeared possibly 1 and $\sim 1.6$ billion years ago, respectively (Butterfield, 2000; Lücking et al., 2009), but prokaryotes had appeared much earlier, 3.8-4.1 billion years before present (Battistuzzi et al., 2004; Schopf, 2006). The span of environments inhabited by microbes is not limited to 
the surface but extends deep underground to $>5 \mathrm{~km}$ (Heberling et al., 2010) and reaches extreme environments which, until recently, were thought to be inhabitable (Rothschild \& Mancinelli, 2001). The second reason to focus on microorganisms is that we know much more about their interaction with minerals than we do in the case of larger living beings because we can both experiment with microorganisms and study them in natural settings in a much simpler and more reliable way. As microorganisms grow faster than larger organisms, their effects are measurable in shorter timeframes, whether in experiments or in natural settings.

The question addressed when searching for the modifications introduced in Earth by microbes, in its simplest form, is: "what do microorganisms do to minerals?". Microorganisms need inorganic nutrients which are, ultimately, stored in minerals. It is reasonable to conclude that microorganisms dissolve or weather minerals in some way in order to release these nutrients. However, because the action of microorganisms is taking place against the background of inorganic processes, the real question to be asked is: "what do microorganisms do to minerals which modifies the inorganic processes, and to what extent are these inorganic processes modified?". For example, microorganisms do dissolve minerals, but they can, at the same time, protect them from dissolution by inorganic agents and the final result may be that mineral substrates populated by microorganisms are less weathered than they would be if these biological populations were not present. What are the changes introduced in the chemistry of phyllosilicate clay minerals (henceforth 'clay minerals', for brevity) produced by weathering as a result of the activity of microorganisms? There are some gaps in our knowledge of global element cycles. For example, it is not clear how the calculated riverine $\mathrm{K}$ input to the oceans is balanced by $\mathrm{K}$ consumption (Berner \& Berner, 2012). Is this imbalance caused by microbial processes not yet accounted for?

Parallel to the questions above, there is the other big issue: what do minerals do to microorganisms? Microbes have to adapt to their habitat and change their activity in order to be successful on mineral substrates of different chemistry, fabric, water content, resistance to weathering, etc. This leads to the expression of different genes in different environments, the change of role of certain species between primary producers and scavengers in microbial populations and, eventually, to evolution. This is a fascinating aspect of mineral-microbe interaction but falls mainly on the biological side and will only be touched on a little here.
At present, investigation of mineral-microbe interaction is still in its infancy. Much of the work done is of experimental character and focuses necessarily on very reduced systems: one or very few microbial species and minerals. These studies collect information that is difficult to compare with other studies and can hardly be extrapolated to natural systems, where there may be tens of minerals and, more importantly, microbial communities with thousands of species interacting very dynamically. Moreover, most of the information that we can gather about microorganisms themselves and about their interaction with minerals is through experimental cultures. As only a small fraction of microorganisms that are recognized in environmental samples (perhaps $\sim 1 \%$ of species; Nealson \& Popa, 2005) can be cultured, we are in the dark about the great majority of them. At present, then, we are at the stage of gathering information, acquiring a few simplistic (some perhaps erroneous) ideas about how minerals and microbes interact, and preparing to use the information when more comprehensive studies are made possible and the work of partial synthesis may start. In spite of the lack of perspective caused by this state of affairs, some authors have tried to scale up their results in order to explore the overall effect that specific mineral-microbe interactions may have now or had in the past. Some examples are provided here because they indicate the scale of the effects produced, which, as expected, have global consequences.

Gathering evidence indicates that submarine basaltic glass is thoroughly colonized by microorganisms. It has been estimated that $\sim 75 \%$ of glass alteration in the upper $300 \mathrm{~m}$ of the ocean crust is microbially mediated (Staudigel et al., 2008) and that colonization of basalts starts right after it cools to $\sim 120^{\circ} \mathrm{C}$, at $1-2 \mathrm{~km}$ depth (Ménez et al., 2012). Experimental work suggests that inorganic alteration of basaltic glass is several orders of magnitude slower than the microbially mediated weathering, and that the latter may alter a layer of $\sim 1 \mu \mathrm{m}$ of glass per year (Thorseth et al., 1995a). From these premises, microbially mediated dissolution of volcanic glass is an important control of ocean chemistry, including $\mathrm{Ca}, \mathrm{Mg}, \mathrm{Fe}, R E E$, and can be considered as an important path of chemical transfer from the mantle to the oceans (Staudigel et al., 1995; Ménez et al., 2012). Interestingly, the alteration products, including clay minerals, are typically enriched in $\mathrm{K}$ far beyond the volume allowed by the altered basalt, indicating extensive exchange with seawater (Thorseth et al., 1995b, 2003; Alt \& Mata, 2000). As a consequence, basalt alteration largely 
enhanced by microbial activity could be a significant $\mathrm{K}$ sink that helps to equilibrate the unbalanced $\mathrm{K}$ budget in the ocean.

The expansion of animal life in the late Precambrian is considered to have been dependent on the increase in the atmospheric oxygen level during that period. The increase in oxygen concentration has been linked to enhanced mineral weathering caused by colonization by the first land biota, fungi, mosses and liverworts, in the Neoproterozoic (from 1 billion years before present; Kennedy et al., 2006). The enhanced weathering would have produced more clay minerals that would have reduced the oxidation rate of organic matter in basin sediments, resulting in the increased oxygen atmospheric level. Some global climatic changes have been considered to be the result of microbial action. Lenton et al. (2012) linked the expansion of non-vascular land plants in the Late Ordovician to an accelerated mineral weathering that increased $\mathrm{CO}_{2}$ consumption in the weathering process itself and by enhancing nutrient levels in the sea. The lower $\mathrm{CO}_{2}$ levels triggered a temperature decrease that generated glaciation events. Lenton et al. (2012) indicated that symbiotic fungi would have been associated with the plants and thus the microbial effect is in fact linked to that of the plants. In a similar way, $\mathrm{CO}_{2}$ levels and climate have been considered to be controlled by fungal-plant associations by way of changing the mineral-weathering activity. Quirk et al. (2014) carried out experiments in which they grew tree saplings associated with mycorrhiza for 6 months in simulated Cenozoic low atmospheric $\mathrm{CO}_{2}$ levels. They found that the intensity of mineral weathering decreased with $\mathrm{CO}_{2}$ levels and interpreted this as a feedback effect to avoid $\mathrm{C}$ starvation. These examples involve plants, which may suggest a counter proof of the much greater relative importance of microorganisms in mineral weathering. However, considering the large interdependence of species across ecosystems, land colonization by plants was probably made possible by the much earlier colonization by prokaryotes ( $\sim 3$ billion years ago; Battistuzzi et al., 2004) and helped greatly, if not altogether made possible, by symbiosis with fungi. Further, the large mass of organic carbon made available by early plant colonization must have boosted microorganism growth and activity enormously.

Etienne \& Dupont (2002) considered that basalt weathering in cold climates is initiated by biological activity and then followed by cryogenic processes. They investigated weathering rinds of basalt in Iceland and interpreted that the biological weathering predated the effect of ice and frost. According to their interpretation, microbial action not only starts the weathering process but also directs it because the physical properties of the rock are modified by the initial chemical alteration induced by the microorganisms. As a result, it would be necessary to reconsider the origin of rock morphology traditionally assigned to the action of ice and frost.

Whether or not the conclusions in the above examples are confirmed by further investigation, they clearly indicate that the implications of mineralmicrobe interactions are important for our planet and that this is an exciting field for research where the most unexpected connections may be found. Importantly, clay minerals are at the core of the examples mentioned: they form from leaching of silicate rocks, act as a K sink and adsorb organic C. Such must necessarily be the case as silicate rocks make up $90 \%$ of the Earth's crust (Richardson \& McSween, (1989)) and are the main source of inorganic nutrients for living organisms (Balland et al., 2010), while clay minerals are the typical products of silicate weathering and are stable or meta-stable in surface and nearsurface conditions, where most of the biological activity takes place. For these and other reasons, such as water-retention capacity, surface-to-volume ratio, cation exchange capacity (CEC), and influence on the configuration of soil fabric, there is no question that clay minerals are central players in the interaction between microorganisms and the lithosphere.

\section{MICROBIAL STRUCTURES}

\section{Biofilms}

Firstly, it is appropriate to consider how microorganisms are in contact with mineral grains. Most frequently, microorganisms generate biofilms, 3-D structures of extracellular polymeric substances (EPS) that contain colonies of multiple species of bacteria, archaea, fungi, cyanobacteria, algae and other microbial eukaryotes, each with a specific metabolic function (Fig. 1). The EPS typically consist of polysaccharides $(50-90 \%)$, proteins and nucleic acids. Biofilms allow microbial communities to attach to surfaces, afford protection from other microbial predators, maintain moisture, control the environment around them, and help microbial cooperation, which includes communication between individuals. Biofilms have channels that allow water circulation and the distribution of nutrients and signalling substances (Fig. 1). Biofilms develop on 


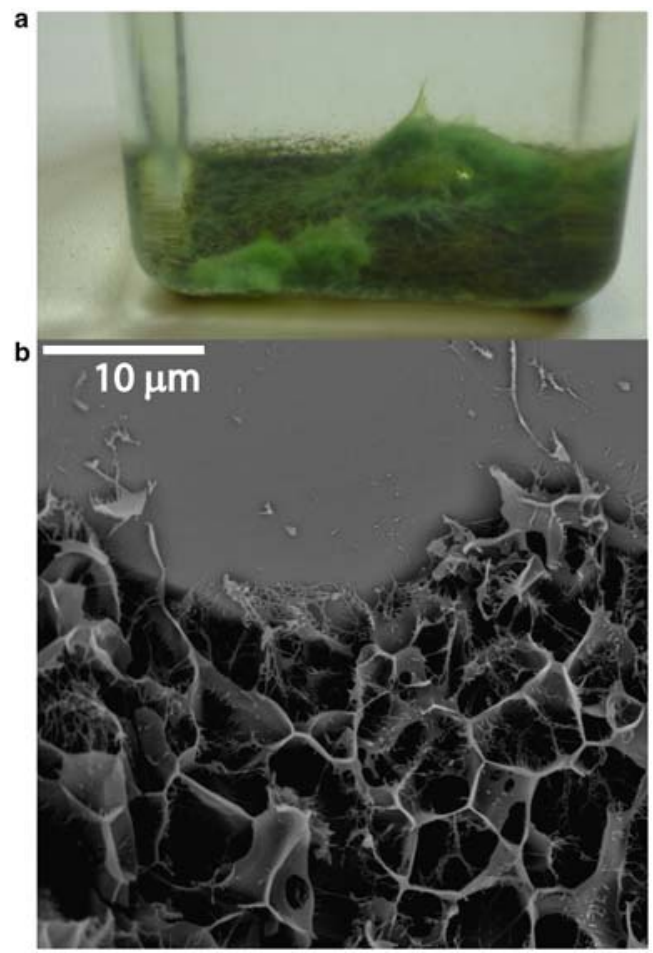

FIG. 1. Microbial biofilms. (a) Photograph of a biofilm, in water, developing attached to grains of ground rhyolitic obsidian, from the experiments of Cuadros et al. (2013a, b). This experiment corresponds to freshwater from a spring. The green colour is due to the growth of algae and cyanobacteria. (b) Inner structure of biofilm attached to a grain of rhyolitic obsidian, revealing a 3-D distribution of chambers and channels. The photograph was obtained using a cryo-SEM to keep the biofilm structure intact (from the experiments of Cuadros et al. (2013a,b).

surfaces submerged in water, in soils and subaereal rock surfaces, and in endolithic environments (de los Ríos et al., 2003). The architecture of the biofilm, extension and thickness depend on many variables, some external as water availability and abundance of nutrients, some internal, such as the composition of the communities living within them, and on some other variables that have not yet been identified. In the case of endolithic biofilms, the space originally available or made so by boring is also a constraint for the biofilm structure. Biofilms not only attach to surfaces but also enclose mineral particles (Fig. 1b).

The interaction between mineral surfaces and microorganisms usually extends to the dimensions of the biofilm and is characterized by the chemical gradient between the external environment and that within the biofilm. Such gradients can be large even if no biofilm exists. For example, respiration of plants and microorganisms in soils can generate partial pressures of $\mathrm{CO}_{2}$ in the soil gas several orders of magnitude greater than that in the atmosphere due to slow gas diffusion (Amundson et al., 2007). The polysaccharide barrier in biofilms obviously increases the chemical gradients across it. Substances secreted by the microorganisms, gases from respiration, mineral species dissolved from the mineral surfaces or actively introduced from the outside, are all more concentrated within the biofilm. At the same time, other species relatively abundant in the outer environment may be significantly diluted within the biofilms. This leads to establishing a concept which is implicitly recognized in the investigation of mineral-microbe interactions but which should probably be stressed more: encapsulation. Microbes are active within specific conditions of water regime, temperature, salinity, water chemistry, etc. and their activity can only be made evident if they modify sufficiently the environmental conditions at the surface of mineral grains. Encapsulation in a biofilm is an effective way of modifying these conditions. If there is no encapsulation, except in the case of endolithic microorganisms, the chemical and physical gradients generated by the microbial activity are less steep and much more restricted spatially. Encapsulation can have effects in every direction of chemical processes, fostering weathering, decreasing it and modifying the weathering products slightly or completely.

Experiments on alteration of rhyolitic volcanic glass in natural waters of different chemistry with their original microbial communities provide an example of the encapsulation effect (Cuadros et al., 2013a,b). We found that in three types of water (hypersaline, freshwater from a lake, freshwater from a spring) the biofilm encapsulated the glass grains completely at the bottom of the bottles where the experiments were carried out. In seawater, the biofilm did not encapsulate the glass grains. At the end of the experiments, in two cases, lake freshwater and hypersaline water, the clay products were different (dioctahedral or trioctahedral) for the biologically and inorganically mediated glass weathering. In these cases, the complete encapsulation in the biological experiments had generated environments with different ion concentrations and $\mathrm{pH}$ than the inorganic controls. The result was that biological and control experiments produced clay minerals with different chemistry. The biological and inorganic weathering products of glass in seawater and spring water were not different. In seawater the lack of 
encapsulation in biological tests prevented major differences from appearing. In the spring water, the water was too dilute to allow for build-up of any concentration of mineral species within the biofilms that could be manifested during the 18 months' duration of the experiments (Cuadros et al., 2013a,b).

\section{Symbiotic structures}

Beside biofilms, two other common ways in which microbes interact with minerals are through symbiotic activity in lichens and plant roots. In lichens, green algae and/or cyanobacteria are symbiotic with fungi. In this symbiosis, the lichen behaves differently from the other elements (algae, cyanobacteria, fungi). The fungus is the element that anchors the lichen to a solid surface through hyphae known as rhizines, although there are also endolithic lichens. If the solid surface to which the lichen attaches is a mineral, the fungus obtains from it the necessary mineral nutrients. Such nutrients can also be obtained from dust, however. The anchoring to rock, soil or sediment surface means that the lichen penetrates them and contributes to rock disaggregation (Adamo \& Violante, 2000), while the leaching activity to obtain mineral nutrients contributes to dissolution (Wilson \& Jones, 1983). However, the coating of the mineral surface is also an effective protection against physical erosion by wind or water, especially in the case of soil and sediments, but also against temperature variations and salt crystallization on rocks (Chen et al., 2000). Lichens have also been found to protect against chemical attack in several ways. They limit rainwater penetration in pores, inhibiting dissolution and precipitation processes, and they frequently create a patina (observed typically in monuments) consisting of calcium oxalate, calcium carbonate and biological debris that appears to protect the rock surface from chemical attack (Chen et al., 2000). Frequently, biofilms develop in combination with the lichens and the effect of the two on the mineral surface is integrated.

Mycorrhizae are fungi that grow in association with plant roots, where plants provide photosynthesized sugars and other organic nutrients to the fungus and the latter provide mineral nutrients and protect against pathogens (acting as a physical barrier and producing antibiotics) and against toxic metals. Mycorrhizae have an extensive network of hyphae that reach much further into the soil than the plant roots, have a much greater combined surface area and a greater ability to leach minerals and take their metal nutrients.
Mycorrhizae and plants can operate separately, but the advantage of the symbiosis for both is evident.

\section{EFFECT OF CLAY MINERALS ON MICROORGANISMS}

Clay minerals have an effect on the physical environment where microorganisms live. Clay minerals have small particle size, large surface area and combined hydrophilic and hydrophobic properties, all of which allow the generation of organo-mineral aggregates and biofilm-mineral structures. The existence of these aggregates is not only a result of life development, but a beneficial factor for it (Kieft, 2000) and specific research investigates the mineral and biological contents and particle dimensions apparently most appropriate for an adequate aggregate architecture (Monreal \& Kodama, 1997). In fact, these aggregates act as an expansion of the biofilms retaining water, organic and inorganic nutrients, and establishing a mineral barrier to the external environment that modifies water, gas and chemical fluxes through the aggregate interior.

Lünsdorf et al. (2000) added soil to sterilized water and inserted a sterilized glass slide on which to allow biofilm formation. After 14 days, the biofilm that developed on the slide consisted of a dense distribution of clay 'hutches', i.e. clay aggregates in the fashion of a house of cards glued together with EPS which contained one to several bacterial cells. The authors interpreted these structures as soil units generated by the bacteria that had been transferred from their original soil habitat to a dispersion in water. Lünsdorf et al. (2000) assigned to the clay structures all the functions that have been mentioned above for soil aggregates, including protection against grazing protozoa. The clay mineralogy was not investigated. Somewhat similar structures were described in natural marine sediments, where small bacterial colonies or single cells were surrounded by EPS and clay particles attached to the surface, more or less tangentially to the EPS surface (Ransom et al., 1999). This structure appears to be almost universal in sediments in aquatic environments, regardless of water chemistry (Ransom et al., 1999). The clay particles, which were not identified mineralogically, showed no visual evidence of leaching. Ransom et al. (1999) suggested that clays may play an important role in providing nutrients that are adsorbed to their surfaces and in eliminating waste products by adsorption on the clay surface or in the interlayer space. Nutrient and waste mobility is slow at the bacterial scale because diffusion is the prevalent 
transport mechanism (due to the strong viscous forces) and thus the proximity of nutrient sources and waste sinks is important. Montmorillonite has been proven to boost microbial activity where kaolinite failed to do so possibly because of montmorillonite expandability and much greater adsorption capacity that leads to exchange of organic and inorganic species and to $\mathrm{pH}$ buffering (Ransom et al., 1999 and references therein). The beneficial effect of the covering of bacteria with clay minerals extends to protection against desiccation and UV light during long-range transport in the atmosphere (Alimova et al., 2009 and references therein). Such protection is only possible by small particles of great adherence, such as clay minerals.

Clay minerals have also been found to benefit biofilms in water. Vieira \& Melo (1995) studied biofilms formed under turbulent flow-mixing suspensions of the bacterium Pseudomonas fluorescens and kaolin particles, comparing them with biofilms formed in the absence of kaolin. They found that the presence of kaolin particles led to greater biomass in the biofilm, to greater stability of the biofilms when their substrate is suppressed, to higher respiratory coefficients of the cells in the biofilms and to quicker mass transfer throughout the biofilm. These results suggest that the kaolin particles both enhance microbial activity in the biofilm and may also change the physical structure of the biofilm, which becomes a stronger and more open matrix.

The description of the physical effect of clay minerals on the microbial environment has brought about another effect, that of the facilitation of nutrients. Clay minerals and Fe-, Al-, and Mn-oxyhydroxides can dominate the solid-water interface in the Critical Zone, even if they are in relatively low abundance, because of their large specific surface area (Chorover et al., 2007). This means that they may be the main players in adsorption-desorption reactions according to their affinity for dissolved or colloidal species, but also that they are the minerals that present a larger surface contact with microbes, their exudates and EPS structures. This intimate contact between clay minerals and biofilms has been addressed above. It follows that clay minerals are important intermediates in the provision of water and nutrients. Water is retained in pores and in the interlayer space of expandable clay minerals from where it can be retrieved. Organic compounds are adsorbed similarly and retained, becoming potentially available rather than being lost (Dröge et al., 1999). However, adsorption of organic matter on clay minerals typically reduces its availability to microorganisms as compared to dispersed organic matter (Kieft, 2000; Curry et al., 2007), and soil and sediment architecture and mineralogy (i.e. clay minerals) may protect organic matter from microorganisms (Van Veen \& Kuikman, 1990; Six et al., 2002).

Microorganisms also require metal nutrients that are taken from minerals, solutions, colloids and decaying organic matter. The metal nutrient requirements that can typically be provided by clay minerals are, in order of decreasing required amounts: $\mathrm{N}$ (ammonium in illite is probably a source of $\mathrm{N}$; Landeweert et al., 2001) $>\mathrm{K}$ $>\mathrm{Na}>\mathrm{Mg}>\mathrm{Ca}>\mathrm{Fe}>>\mathrm{Mn}, \mathrm{Co}, \mathrm{Zn}, \mathrm{Cu}, \mathrm{Si}, \mathrm{Ni}$ and Mo (Prescott et al., 1999; Frausto da Silva \& Williams, 2001; Todar, 2016). Different clay minerals, and minerals in general, have different composition and resistance to leaching. If microorganisms are to dissolve minerals or degrade them in some way to free some of their components, they have to use different intensity of leaching or procedures depending on the mineral concerned. For example, smectite is much more nutrient-rich than kaolinite. Other things being equal, microorganisms living in kaolinite-rich environments will need to be more aggressive, in order to solubilize sufficient nutrients, than in a smectite-rich environment. Obviously, because most environments are not monomineralic, microorganisms can identify the minerals in the system that are most nutrient-rich and leachable, and concentrate their attack on them. In any case, this is a way in which minerals affect microorganisms enormously because microorganisms have to adapt to the inorganic conditions of the environment. The organization and activity of microbial populations are also affected by minerals. Carson et al. (2007) investigated the effect of changing mineral composition of the soil on the microbial structure. They used microcosm experiments in which they added mica, basalt and rock phosphate (consisting mainly of calcium phosphate) in several combinations and with different plants or with no plants. The community structure of bacteria and fungi were significantly affected by the mineral addition (and also by the plants grown), i.e. the relative activity of the several species changed together with the mineralogical changes.

In an experimental study, Balland et al. (2010) found that the type of mica (biotite or phlogopite) in bacterial cultures controlled how bacteria attacked the mineral. Solubilization of the same amount of $\mathrm{Fe}$ required greater production of organic acids for biotite than for phlogopite. Iron can be released in several ways, mainly by acid dissolution, secretion of siderophores (Balland et al., 2010) and $\mathrm{Fe}$ reduction, leading 
typically to partial mineral dissolution (Kuhn et al., (2013)). Microbes may have to use more than one strategy (Kuhn et al., (2013)) or switch from one to another in order to be effective in the Fe-extraction process. Xiao et al. (2012) investigated changes in the genetic expression of the fungus Aspergillus fumigatus with and without readily available $\mathrm{K}$. In some experiments the only $\mathrm{K}$ supply was K-bearing minerals, which induced increased expression of fungal genes related to mineral weathering, such as production of organic acids, metal-binding proteins and $\mathrm{CO}_{2}$, to accelerate dissolution.

The ways in which microorganisms adapt to the specific requirements of mineral-nutrient availability, resulting in the control of the microbial activity by the environment, are many. Some of these are listed here. The switch between potentialities for mineral attack possessed by the microorganisms has been indicated above. Horizontal gene transfer, a process (other than generation of new individuals) in which part of the genetic code is transferred between organisms, is common between microorganisms. This process allows individuals from a species to acquire new capacities and to transmit them to its offspring. Thus, communities of species developing on minerals can transfer mineral attack potentialities beneficial for the specific mineral environment to other species that do not have such potentialities, thus increasing their adaptation to the particular environment. Uroz et al. (2009) suggested that the bacterial genus Collimonas, living in terrestrial environments, has acquired its efficient mineral weathering capacity from mycorrhizal fungi. Interestingly, clay minerals facilitate lateral gene transfer and do it in more than one way. Clay minerals can fix cells and viruses to their surfaces, which facilitates cell-cell and virus-cell contacts (the gene transfer can be carried out through different routes, including inoculation by viruses). Also, clay adsorbs DNA and protects it from rapid degradation, facilitating DNA uptake by cells (Dröge et al., 1999).

One other adaptation to the environment is the generation of ecological structures in which different species carry out different functions that allow better use of available resources. Some of these communities are recognizable directly because they produce layered microbial communities, i.e. the several species are distributed spatially according to their activity. One such structure was described from the rock-lichen interface, where four zones were found from rock surface to the upper thallus of the lichens, with distinctive weathering and biological features, indicating the activity of different microorganisms and the lichens (Barker \& Banfield, 1996). It is obvious that the microorganisms and lichens provide the several nutrients needed by the entire community through their autotrophic or heterotrophic nutritional activities. Soil crusts are associations of soil particles and cyanobacteria, algae, microfungi, lichens and bryophytes. They develop at the top of soils, most frequently in arid and semi-arid climates, and generate a coherent layer which stabilizes the soil (Belnap et al., 2001). The mineral particles and every biological species fulfil a function that benefits the community and the wider ecosystem, from fixation of atmospheric $\mathrm{N}$ and $\mathrm{C}$ (Grote et al., 2010) to protection against damaging radiation and holding together of the crust (Belnap, 2003). Clay and other mineral particles provide the building bricks of the crust, protect against radiation and desiccation, and contribute inorganic nutrients.

There are other ways in which clay minerals influence microorganisms that are far from obvious. Courvoisier \& Dukan (2009) investigated the effect of kaolinite on Escherichia coli cultures and found that kaolinite promoted quicker cell division and a greater number of cells. The authors suggested that the kaolinite promoted a decrease in catabolic activity and an increase in the assimilation of acetate by transferring part of the energy outcome from acetate degradation to cell division rather than to cell maintenance. Thus, the increased number of cells could be explained, but the faster cell division was not necessarily so. Courvoisier \& Dukan (2009) suggested that these effects were unrelated to the adsorption properties of kaolinite but could not describe the specific mechanism involved. Clay minerals can apparently alter the metabolic routes of microorganisms in ways other than providing or retrieving nutrients from the environment.

\section{CLAY-MINERAL FORMATION MEDIATED BY MICROORGANISMS}

\section{Clay-mineral precipitation from solution}

The question set at the beginning of the article "what do microorganisms do to clay minerals?" is addressed in this and the following sections. In the first place, the formation of clay minerals is considered. Microorganisms precipitate clay minerals from solutions (including colloidal components) and through the weathering of silicate minerals. Formation of new clay minerals from other previously existing clay minerals or from large-grained phyllosilicate species can be considered a special case given the structural similarity 
of parent and product minerals and will be dealt with separately as microbially mediated 'transformation'.

It is probably safe to say that clay minerals of microbial origin are typically of variable composition and low crystal order; or rather, that they have a more variable composition and lower crystal order than clay minerals formed by inorganic processes in the same environment (Douglas \& Beveridge, 1998). Bacteria from biofilms in the solute-rich waters of the Rio Solimões, Brazilian Amazon basin, were found to be covered, each of them individually, with very fine particles of variable Si-Al-Fe composition and claymineral morphology (Konhauser et al., 1993). The process of their formation was suggested to have started with accumulation of $\mathrm{Fe}$ on the membrane of the individual cells, followed by trapping of $\mathrm{Al}$ and $\mathrm{Si}$. A chamosite-like composition was frequent in the particles, but there was no detectable crystal structure and progressive crystallization correlated with a change into a kaolinite-like composition. The process took place in bacteria of different species, suggesting that the phenomenon is a case of passive clay mineralization linked to the anionic nature of the cell wall, rather than to bacterial activity. In an experimental set up with similarities to the previous study, Tazaki (2005) incubated sediments from the Passo Real Dam (Portalegre, Brazil) by placing a glass slide on the sediment (bottom) and leaning it against the side of the incubation vessel. In this way, the biofilms forming on the glass slide were free of pre-existing sediment and contained only newly formed minerals. The sediments consisted mainly of kaolinite, quartz, cristobalite, feldspar and presumably some Fe oxide, given the reddish colour of the sediment and the composition of the newly formed clay. Spheres of a Si-Fe-rich mineral, with little $\mathrm{Al}$, were observed in contact with bacterial cell walls and also detached from them. The spheres displayed X-ray diffraction (XRD) peaks consistent with halloysite. They were interpreted to form and develop on the bacterial cell walls, to mature there and then detach. The results from this study and that of Konhauser et al. (1993) are very similar and point to a central role of $\mathrm{Fe}$ in the nucleation of clays on bacterial cells.

At near-neutral $\mathrm{pH}$, the bacterial cell walls and the EPS have a net negative charge in their surface produced by carboxylic, hydroxyl and phosphoryl groups, so they can attract and retain cation species. They also have localized amino groups charged positively, which allow attachment of silicate anions. Interaction of negatively charged sites on cell walls and anions can also take place through cation bridging
(Kawano \& Tomita, 2001). The combination of all these sites on bacterial walls and attachment mechanisms explains how they can be effective nucleation agents for clay minerals (Douglas \& Beveridge, 1998; Kawano \& Tomita, 2001). The biological crystallization process, however, may not be caused only by the existence of an adequate template with the correct array of functional groups. Fiore et al. (2011) carried out experiments lasting up to 322 days with kaolinitesaturated solutions in the presence/absence of oxalate and bacteria from peat-moss soil. A white precipitate developed in a few days. Macroscopic techniques (XRD, Fourier transform infrared spectroscopy FTIR) could not detect crystalline phases, but high-resolution transmission electron microscopy (HRTEM) with microanalysis detected kaolinite. Fiore et al. (2011) suggested that kaolinite formed in two steps: (1) precipitation of an aluminosilicate gel by the action of oxalate and organic products (EPS, biofilm, metabolites); and (2) crystallization of kaolinite induced by the metabolic activity of bacteria found within the gel.

The Si-Fe-Al composition of the clay mineral precipitated on the surface of the bacteria has been corroborated in other studies (e.g. Konhauser \& Urrutia, 1999; Kawano \& Tomita, 2001), and the EPS of biofilms seem to play a role similar to that of the bacteria cell walls. Nontronite from submarine sediments related to hydrothermal vents and metalliferous sediments (where $\mathrm{Fe}$ is abundant) typically has a very characteristic worm-like morphology of curved rods with a flaky surface. Ueshima \& Tazaki (2001) found nontronite embedded in EPS in sediments from the Iheya Basin (Japan). When observed with TEM, the nontronite layers appeared to be oriented within the EPS material. The suggestion was that the EPS catalyses the precipitation of nontronite, as was described above for the bacterial cell walls. Ueshima \& Tazaki (2001) found evidence supporting this hypothesis by mixing a natural ferrosiliceous groundwater with polysaccharides (dextrin and pectin). The result was the formation of nontronite, while a blank experiment, without the polysaccharides, produced $\mathrm{FeOOH}$ with an adsorbed $\mathrm{SiO}_{2}$-rich precipitate. Sanchez-Navas et al. (1998) found Si-Fe-Al smectite and gels of variable composition in Jurassic phosphate stromatolites from a pelagic environment. Those authors offered the interpretation that Si-Fe-Al gels were precipitated within the bacterial biofilms in a process similar to those described above and then the gels recrystallized partially to produce smectite. They suggested that this type of process could be a common 
precursor of glauconite given the similarity of settings, although in the studied case there was no evolution to glauconite. Indeed, the generation of Fe-rich smectite is the first step in the formation of glauconite. Ironsmectite precipitates within shells, faecal pellets and calcareous and siliceous bioclasts near the sedimentwater interface in shallow and deep marine environments (Chamley, 1989; Baldermann et al., 2013). These are environments with high concentrations of organic matter which favour microbial activity. Here again is a connection between microbial presence and precipitation of a $\mathrm{Si}-\mathrm{Fe}-\mathrm{Al}$ clay mineral. The formation of other Fe-rich "verdine facies" (Chamley, 1989; Huggett et al., 2006) with $d$ spacings of $\sim 7$ and $\sim 14 \AA$ in similar environments is probably related to microbial activity also.

Young basaltic tephra from the Kilauea volcano (Hawaii) that had been deposited between 1500 and $1790 \mathrm{AD}$ was investigated by Konhauser et al. (2002). The alteration of the tephra was mainly due to hydrothermal action of steam vents (in the 3 years prior to sample collection, the maximum temperature was $80^{\circ} \mathrm{C}$ ) and there were clear signs of significant alteration, mobilization and precipitation of secondary phases (amorphous $\mathrm{SiO}_{2}$ and goethite). Biofilms were present that could not be related to the alteration action, but showed precipitation of clay mineral phases attached to the cells (species not identified) within the biofilms. The clay minerals had a composition consistent with a Si-Al-Fe-K dioctahedral smectite in which $\mathrm{Al}>\mathrm{Fe}$. The formation of this smectite appeared to be caused by intake of the ions from the fluids into the biofilm, where they concentrated and precipitated on the cell walls. A different type of biomineralization was found in another stratum of the biofilm, where $\mathrm{SiO}_{2}$ with minor $\mathrm{Al}$ precipitated on cell walls (in this case probably cyanobacterial species).

The action of bacterial walls as nucleation points for clay minerals can have important implications for soils. Urrutia \& Beveridge (1995) showed that this effect may overcome the inhibition of precipitation caused by dissolved organic ligands that act as metal complexation agents. Precipitation of aluminosilicates of allophanic composition (no Fe available) with shortrange crystal order took place in the experiments by Urrutia \& Beveridge (1995) in the presence of citric, tannic and fulvic acids. The implication is that bacteria passively promote clay precipitation in soils against the metal complexing action of organic ligands. This may be an important mechanism to protect soils from chemical erosion by dissolution and transport of solutes.

\section{Do microorganisms enhance mineral weathering?}

So far, the focus has been on clay precipitation from solutions, in water media or in soil or sediments, without reference to the minerals that shaped the chemistry of the waters. Now the focus changes to clay formation from the dissolution of silicates as the process can be followed from the dissolution of the specific parent mineral to the precipitation of the clay mineral. In certain cases, however, there is no real dissolution of the parent mineral, as the neoformed clay mineral has a strong structural connection to that of the parent mineral. One important question is whether microbial activity enhances or decreases silicate weathering. Examples have been found of both enhanced weathering or dissolution and of protection. So far, the evidence seems to be for a net effect of fostering mineral weathering but this may be a bias resulting from the type of studies carried out, typically simple experimental systems operating for very short times. Besides, in many of these experiments microbes are forced to attack minerals in order to obtain the necessary mineral nutrients that may be obtained from other sources in the more complex and developed ecosystems. The fact that mineral dissolution rates in nature are orders of magnitude smaller than those measured in the laboratory may be related to microbial (or biological in general) activity (Moore et al., 2012).

Recognized ways of mineral weathering induced by microorganisms include the following: (1) acid attack produced by the release of protons, $\mathrm{CO}_{2}$, carbonic, phosphoric, aliphatic or aromatic acids, and the action of EPS, which have acidic groups (Bigham et al., 2001; Uroz et al., 2009); (2) exudation of chelating agents, such as oxalic or citric acid, siderophores and EPS, that bind to metals (mainly $\mathrm{Fe}$ and $\mathrm{Al}$ ) and displace the equilibrium of mineral weathering towards further dissolution (Adeyemi \& Gadd, 2005; Balogh-Brunstad et al., 2008); (3) element oxidation-reduction (mainly $\mathrm{Fe}, \mathrm{Mn}, \mathrm{S}$ ), which promotes mineral breakdown and dissolution (Bigham et al., 2001; Hopf et al., 2009); (4) uptake of dissolved ions by adsorption into cell walls or assimilation, a process which also displaces the chemical reactions towards further dissolution; (5) local modification of the water chemical composition (e.g. concentrating salts) and/or viscosity. These modifications cause the solution to become more aggressive to the mineral surface, favouring cation exchange and penetration of organic molecules into the mineral lattice (Brehm et al., 2005; Cuadros et al., 
2013a,b). (6) Increase of $\mathrm{pH}$ is less common but has also been reported as a mechanism of feldspar (Barker et al., 1997) and volcanic-glass dissolution (Thorseth et al., 1992), especially effective in the latter case. These mechanisms of chemical attack are sometimes combined with the physical erosion of mineral grains by microbial growth and movements, which fosters mineral weathering by exposing fresh surfaces to chemical attack (Gazzè et al., 2012; Li et al., 2016).

Microbial activity may also retard mineral attack in a variety of ways, however. Biological weathering may generate stable secondary mineral phases that coat tightly and protect the mineral grains. Development of EPS and biomats generate enclosed fluid-mineral interfaces in chemical equilibrium where mineral dissolution slows down (Valsami-Jones \& McEldowney, 2000). Some of the polymeric substances in EPS adsorb irreversibly on mineral surfaces or react with minerals and solutions generating new stable phases protecting the mineral surface (Ullman et al., 1996). In arid areas the formation of an amorphous precipitate may be sufficient to protect the mineral surface from further weathering (Benzerara et al., 2005). The above mechanisms of mineral protection are possibilities but there are are other possible complex mechanisms which are more difficult to foresee. For example, Lawrence et al. (2014) modelled the development of soil at long scale using oxalic acid as a leaching and complexing agent, and including a score of physical and chemical variables related to the fabric, mineral content (parent and precipitated in the process) and oxalic acid long-term behaviour (transport, metal complexation, mineral surface complexation, decomposition of oxalic acid). Surprisingly, the model indicated that, although oxalic acid addition increased the rate of mineral dissolution at the soil surface, the overall effect on the soil was a decrease in chemical weathering. It is likely that no single factor acts in a single direction, towards faster or slower weathering, but that weathering is controlled by several variables. As an example, Banfield et al. (1999) found that, in lichens, EPS can both suppress or enhance mineral weathering rates by up to three orders of magnitude, depending on $\mathrm{pH}$, composition and structure of the mineral surface and organic functional groups in the EPS polymers.

\section{Clay-mineral formation from other silicate minerals}

Volcanic deposits are rich in mineral nutrients that can be extracted easily given the labile character of glass, and thus they are colonized quickly by microorganisms. The result is the rapid development into soils. Kawano \& Tomita (2001) reported bacterial counts in the volcanic ash deposits of Kaimondake (4040 ybp) and Koya (6400 ybp), in Japan, similar to those in mature soils $\left(10^{8}-10^{9}\right.$ cells $\left./ g\right)$. Bacterial cells in the deposits were covered with the familiar lowcrystal order Si-Fe-Al clay minerals. Their composition varied between proto-imogolite allophane and chamosite, and their habit was fibrous to flaky and smectite-like. They also found granular masses with $\mathrm{Si}$, $\mathrm{Al}$ and minor Fe. Spots without bacteria were altered to a slightly different phase, allophane, with an $\mathrm{Al} / \mathrm{Si}$ ratio of $1-2$.

Cuadros et al. (2013a,b) carried out experiments of rhyolitic glass weathering in natural waters of different composition (hypersaline, seawater, fresh water from a spring and from a lake) with their original microbial communities. Some experiments lasted 6 years, most of them 18 months (Cuadros et al., 2013b). Their goal was to see how the microbial action would modify the inorganic alteration, which, in principle, could be different for the several waters given their different composition and $\mathrm{pH}$ (the fresh water from the lake had a $\mathrm{pH}$ of 9). Addition of glucose and peptone boosted microbial development and the generation of thick biofilms that, in most cases, incorporated the grains of volcanic glass. The 18-month experiments produced very small amounts of clay minerals that could only be detected using TEM and scanning electron microscopy (SEM) (Fig. 2). The clay-mineral products indicated that the microbial modification of the inorganic alteration depended on the water chemistry and the degree of confinement of the volcanic glass within the biofilms. Inorganic alteration produced mainly a dioctahedral, Al-rich clay mineral (possibly beidellite), that appeared to develop from the surface of glass grains. In hypersaline water, the confinement of the glass grains within the biofilm, where solute concentrations were high, caused the precipitation of trioctahedral, Mg-rich clay minerals (probably saponite). In the fresh-water lake experiments the results were inverted because the high $\mathrm{pH}$ of the water and $\mathrm{Mg}$ concentration favoured formation of the Mg-rich clay mineral in abiotic experiments whereas the biological experiments decreased the $\mathrm{pH}$ within the confined space of the biofilm and displaced the composition of the clay mineral formed to Al-rich. The fresh water from the spring had low cation concentrations and the corresponding concentrations within the biofilms were probably never high, so that there was no difference between the composition of the biologically and 


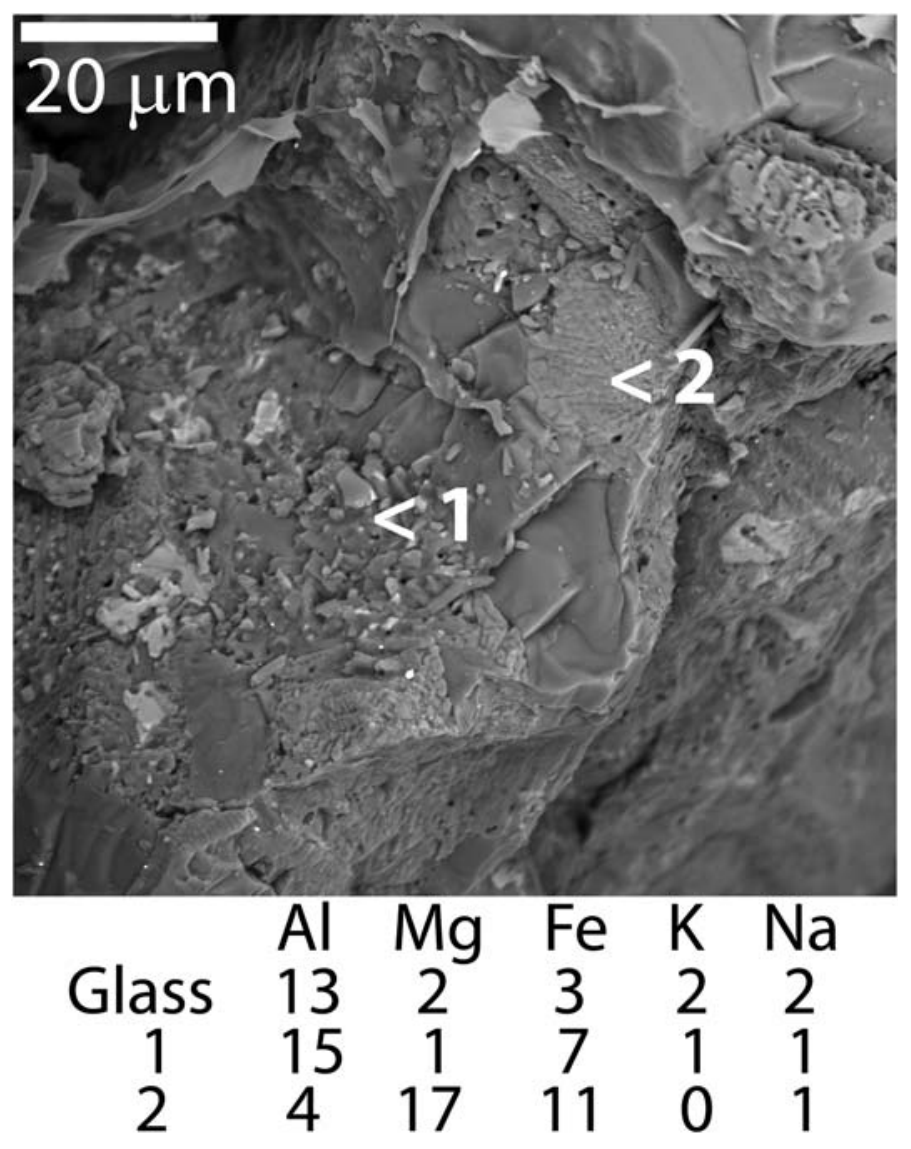

FIG. 2. SEM image (secondary electrons) and EDS analyses of rhyolitic volcanic glass altered in spring water with microbial activity boosted by the addition of organic nutrients and lasting 18 months (Cuadros et al., 2013a,b). The numbers indicate the relative composition (normalized to $\mathrm{Si}=100$ ) of the areas analysed. The pristine glass analysis was from a nearby area. The other two analyses correspond to the points indicated in the image. Point 1 indicates alteration to a dioctahedral 2:1 clay mineral. Point 2 indicates alteration to a trioctahedral 2:1 clay mineral (modified from Cuadros et al., 2013b).

inorganically altered glass. In the seawater, the biofilms did not confine the glass grains, which then experienced alteration by water of similar composition in the biotic and abiotic experiments. The $\mathrm{Mg}$ concentration in seawater was not sufficient to produce Mg-rich clay minerals and the product was a dioctahedral Al-phyllosilicate. The long experiments (6 y) produced very small amounts of clay phases, but both biotic and abiotic experiments produced the very surprising result that the volcanic glass chips were entirely transformed into quartz and alunite (Cuadros et al., 2012).

Formation of clay minerals promoted by microorganisms is not restricted to the surface, as microorganisms are active deep underground (up to $\sim 5 \mathrm{~km}$ ), both in the continental and oceanic crust. There is much literature about microbial attack of oceanic basalt and some authors consider that it supports an ancient (going back to the origin of life) and vast population of microorganisms from the water-basalt interface to the roots of the oceanic crust (Staudigel et al., 2008; Ménez et al., 2012). Life in the deep oceanic crust would be supported by the serpentinization reactions that can be written in a general form as: olivine+ pyroxene + water $\rightarrow$ serpentine \pm brucite \pm magnetite + hydrogen. These reactions are also linked to the generation of methane. Hydrogen and methane can be oxidized and become the source of energy for microbial communities (McCollom \& Seewald, 2013). Microbial alteration of basaltic glass ranges from 
simple dissolution to formation of non-crystalline phases to clay-mineral formation. Thorseth et al. (1995a) carried out experiments with bacteria on basaltic glass lasting 10 to 394 days. The $\mathrm{pH}$ of the medium decreased from 8.0 to 5.8. The bacteria had great affinity for the surface of the glass and the authors found dissolution tracks on the glass generated by the bacteria after 49 days. However, it was not until 181 days that the glass showed chemical changes, when a leached layer $\sim 1 \mu \mathrm{m}$ thick developed, depleted in all cations and enriched in Si. The glass alteration rate was $\sim 10$ times faster than that of the abiotic experiments. Supposedly, the leached layer is a reactive area where clay formation would take place in longer experiments. This is a typical example of results from experimental biological alteration of basaltic glass. As our focus here is clay minerals, the following examples correspond to cases where clay minerals formed. Thorseth et al. (2003) investigated alteration of basaltic glass from the seafloor within the age range $0-30 \mathrm{Ma}$ in the Australian Antarctic Discordance, an ocean-spreading centre. The recent basaltic glass was populated heavily with microorganisms and there were numerous pits on the surface in intimate contact with them. The main secondary minerals found in altered areas were interpreted to be zeolites. Another alteration product with a beidellitic composition was also present in areas apparently altered inorganically. Most of the glass alteration, biological or inorganic, took place before glass burial in subsequent lava flows. This study illustrates the large microbial activity taking place in ocean spreading centres due to the high temperatures (faster metabolism) and large abundance of mineral nutrients that allow the development of complex communities using a wide range of energy sources (Zierenberg et al., 2000). Certainly, these are hot spots of mineral-microbe interaction.

In another investigation of microbial activity deep underground, Hama et al. (2001) cultured bacteria from the Äspö (Sweden) groundwater with crushed diorite. They found an enhanced formation of clay minerals under the action of the bacteria. The clay minerals may have been different in biological and abiotic experiments. According to the authors, mixedlayer chlorite-smectite and smectite were the product in biological experiments and smectite in the abiotic tests. Certainly, the XRD patterns of the two products were different but their specific mineralogy could not be assessed with the information provided in the article. The mechanism of clay formation in the biological experiments appeared to be precipitation from solution induced by microenvironments created by the bacteria and their exudates.

In lichens, the element in contact with the mineral substrate is a symbiotic fungus and weathering by lichens also illustrates generation of clay minerals by microorganisms. Barker \& Banfield (1996) studied a naturally weathered lichen-encrusted amphibole syenite boulder containing feldspar, ferriannite mica, quartz and ferrohastingsite amphibole. The authors did not observe a leached layer between parent and secondary minerals. The surface of the parent mineral was coated with EPS which engulfed completely the secondary phases that grew immediately next to the unleached primary minerals. Clay minerals had homogeneous composition that depended of the altered primary mineral, an Al-Si phyllosilicate in the case of feldspar and quartz, an Fe-Si phyllosilicate (possibly nontronite) in the case of the amphibole. The clay-mineral particles were oriented face-to-face with respect to each other. The weathering process was a combination of dissolution, transport of selected elements and recrystallization. No contact was observed between microbial cells and the clay products, and it was suggested that the EPS were the agents responsible for the weathering. By contrast, mineral grains not coated by the lichen showed only alteration of the amphibole, with the formation of an Fe-Si smectite that grew topotactically oriented to the amphibole and goethite.

Experiments by Ascaso \& Galvan (1976) demonstrated that acids secreted by lichens can weather silicate minerals into clay minerals. They used lichen acids (acids that are generated only by lichens) and oxalic acid (more universally produced, especially by non-symbiotic fungi) and several minerals and rocks. The weathering products could only be observed using TEM. As there is no mention of EDS analyses, it is assumed that the identification of the clay minerals was based on the particle morphology. Ascaso \& Galvan (1976) found that tubular halloysite was produced by reaction of granite and the several acids, as well as of albite with stictic acid. Smectitelooking particles (interpreted as montmorillonite by the authors) were generated by the reaction of albite and oxalic acid.

There is a variety of other studies indicating clay-mineral formation by biological activity in subaereal environments; their identification or their biological origin has not been demonstrated unambiguously, however, and they are not included in this review. 
Transformation of clay minerals promoted by microorganisms

The cations that are leached most easily are those in the interlayer space of clay minerals $(\mathrm{K}, \mathrm{Ca}, \mathrm{Na}, \mathrm{Mg})$ as they can be released by cation exchange, even in the case of micas. Typically, $\mathrm{K}$ is the first cation to be released from micas in microbial weathering experiments of micas, or is released in larger proportions than lattice cations (Balogh-Brunstad et al., 2008; Hopf et al., 2009; Boneville et al., 2011). Transformation of mica into vermiculite and smectite are typical processes of microbial weathering (Barker et al., 1997). Also, vermiculization (regular mixed-layer biotite-vermiculite) was produced by lichen weathering of biotite that otherwise preserved the lattice intact (Barker \& Banfield, 1996). Potassium may be released by exchange with protons, due to microbiallymediated acidification, or with other cations (e.g. Ca, $\mathrm{Na}$ ). Wierzchos \& Ascaso (1996) found that biotite weathered by lichens had been depleted in $\mathrm{K}>>\mathrm{Fe}>$ $\mathrm{Ti} \sim \mathrm{Mg}$, and enriched in $\mathrm{Ca}>\mathrm{Na}>\mathrm{Al}>\mathrm{Si}$, where $\mathrm{K}$ was probably displaced by $\mathrm{Ca}$ and $\mathrm{Na}$ that were released in the dissolution of $\mathrm{Ca}$ - and Na-rich minerals. The result was an interstratified biotite-vermiculite. Cation exchange was also the process taking place in experiments of vermiculite with anaerobic bacteria, although in this case $\mathrm{K}$ was exchanged for $\mathrm{Mg}$, the main interlayer cation present originally (Perez Rodriguez et al., 1989). Those authors suggested that $\mathrm{Mg}$ is an essential cation for bacterial activity, as supported by other results in their study.

Another K-depleting reaction was found by Arocena et al. (2012) in biotite. Those authors inoculated the mycorrhizal fungus Glomus into the roots of several crops that were grown on a mixture of quartz sand and biotite over a period of 100 days. The fungus caused the alteration of biotite to illite, smectite, mixed-layered phases and hydroxy-interlayered vermiculite, as shown by the XRD investigation, while leaving some biotite intact. In parallel experiments of the crops without the fungus symbiont, all the biotite was altered to similar K-depleted phases. These results are interesting because, the authors suggested, the mycorrhizal fungus is selective in terms of leaching activity as a way of preserving the source of $\mathrm{K}$ for longer. The plants, it seems, have not acquired this adaptation and they leach the biotite indiscriminately.

Microbial action not only causes weathering reactions, it also causes reactions in the opposite direction. This point requires further study in order to assess the real extent and global relevance of the reverse process mediated by microbes. This is made more interesting because typically, microorganisms are linked to mineral-weathering processes only. The transformation of smectite to illite requires increase of the layer charge and uptake of $\mathrm{K}$ or $\mathrm{NH}_{4}$. Smectite typically contains $\mathrm{Fe}$, sometimes its most abundant octahedral cation. Iron reduction is a quick and effective way (no cation replacement in the lattice is required) to increase the layer charge. If $\mathrm{K}$ or $\mathrm{NH}_{4}$ are available during the $\mathrm{Fe}$ reduction process in smectite, the formation of illite will follow. The reduction of Fe can take place by direct action of Fe-reducing bacteria which obtain their energy from this process, or because the environment has a sufficiently low Eh to reduce $\mathrm{Fe}$ in smectite layers. In near-surface environments, such low Eh values are typically linked to microbial activity because some agent is required to consume oxygen diffusing into the system. Decaying organic matter might be this agent, but the presence of some organic matter is inevitably linked to that of microorganisms feeding on it. Glauconite maturation is a typical example of smectite illitization by $\mathrm{Fe}$ reduction. Glauconite is widely held to form by replacement of Fe-rich smectite precipitated within shells and faecal pellets near the sediment-water interface in shallow and deep marine environments (Baldermann et al., 2013). This setting is ideal for reduction of $\mathrm{Fe}$ in smectite given the concentration of organic matter in these microenvironments. Potassium is available from seawater, provided that sediment porosity is appropriate. Recently, the context of glauconite formation has been widened as it has been shown to extend to soil and lacustrine environments (Huggett \& Cuadros, 2010), again linked to reducing conditions (cyclical in this case due to wetting and drying cycles), implying waterlogging and microbial activity, as well as $\mathrm{K}_{\text {and }} \mathrm{NH}_{4}$ availability. The same process generates Fe-rich illite, whether it can be defined as glauconite or not, in similar environments (Huggett \& Cuadros, 2005). Special mention can be made of mangrove forests in tropical and subtropical areas, where Fe-illite is generated in large amounts from detrital kaolinite and goethite, via mixed-layer kaolinite-smectite and illitesmectite (Andrade et al., 2014; Cuadros et al., 2017). Here the process requires the initial formation of smectite from kaolinite which takes place in the cationrich $\left(\mathrm{Si}, \mathrm{Mg}, \mathrm{Na}, \mathrm{Ca}, \mathrm{K}, \mathrm{NH}_{4}\right)$ environment of the mangroves where $\mathrm{Fe}$ is cyclically made available as dissolved $\mathrm{Fe}^{2+}$ through reduction processes mediated by microorganisms. 
Illitization through burial diagenesis is controlled mainly by inorganic factors and the layer charge results mainly from Al-for-Si substitution. $\mathrm{Fe}$ is usually present in smectite and $\mathrm{Fe}$ reduction is a potential source of negative charge, however. Underground thermophilic bacteria (they operate at temperatures of $>60^{\circ} \mathrm{C}$ and potentially well above $100^{\circ} \mathrm{C}$ ) have been found able to carry out such processes and they may contribute to smectite illitization in diagenetic settings (Zhang et al., 2007a).

\section{DISSOLUTION OF PHYLLOSILICATES}

The investigation of experimental dissolution of phyllosilicates by microorganisms is biased towards the use of minerals with large particle size, such as mica, chlorite or vermiculite. The reason is that large crystals allow the investigation of the mineral surface after the experiments, which provides two types of information: (1) direct indication of chemical changes taking place in the mineral; and (2) clues about the mechanisms through which the leaching took place. The first type of information simplifies the investigation tremendously. If fine-grained clay minerals are used, it is more difficult to measure chemical changes directly on the mineral surface (particles are $\mu \mathrm{m}$ size and vary in composition). In this case, the investigation of the chemical changes in the mineral requires the chemical analysis of the solution (if there was a liquid medium), of the microbial mass and of secondary precipitates as well as to estimate the global amount of these precipitates. The precipitates can also bias the real composition of the altered fine-grained phyllosilicate if they are not separated from it. The investigation of the mechanism of alteration of phyllosilicates is also much more difficult in experiments with very small particles. In such a case the mechanism needs to be deduced using indirect methods, e.g. analysing the solution, secondary precipitates, substances secreted by the microorganism, etc. For these reasons most of the investigations in the literature are based on coarsegrained phyllosilicates. The use of XRD, when possible (due to the size of the samples and the extent of the dissolution), can indicate mineralogical and chemical changes that are linked to dissolution processes.

Microorganisms are able to dissolve minerals by direct contact with them and without contact. The contact processes leave edges and pits with the approximate shape of the organism (or part of the organism) that produced the dissolution. The non-contact processes produce many different morphologies and patterns. It is not clear which of the two mechanisms is more frequent. Apparently, most microorganisms are able to act in both ways and it is not known what are the variables that promote contact or non-contact dissolution. The two mechanisms are most apparent in fungi. Li et al. (2016) estimated that $40-50 \%$ of the dissolved mass of lizardite in a culture in water medium of the fungus $T$. flavus (isolated from the rhizospheric soil in a serpentine mine) was caused by direct contact of spores and hyphae of the fungus with the mineral surface. Round and elongated pits, produced by spores and hyphae, respectively, were observed using atomic force microscopy (AFM). The chemistry in these pits indicated local chemical changes and Li et al. (2016) could measure local $\mathrm{pH}$ decrease. They concluded that only fungal cells attached to the lizardite released siderophores. Hyphae were more aggressive than spores in their attack as the former caused complete breakdown of the crystal structure of lizardite in the pits, while the spores did not. An important component of the hyphal attack is their high pressure on the mineral surface (10-100 MPa; Li et al., 2016, and references therein) combined with the lateral shear pressure caused by the hyphal growth, which are sufficient to deform and break the mineral crystal lattice. Spores exert much less pressure. The results of Li et al. (2016) contrast with those of Balogh-Brunstad et al. (2008), who estimated that only $1 \%$ of the dissolution rate of biotite weathered in a culture of Suillus tomentosus (an ectomycorrhizal fungus) in water medium was produced by contact of the fungus with the mineral. This dissolution was produced in shaken experiments, and the marks of contact dissolution on the biotite were observable with AFM. If the experiments were not shaken, no marks appeared on the biotite, indicating no dissolution by contact. Fungal hyphae attached to the biotite surface in all experiments, shaken and not shaken. Balogh-Brunstad et al. (2008) concluded that biotite dissolution occurred mainly by acidification of the bulk liquid and by cation complexation. Dissolution of biotite was 2-3 orders of magnitude quicker in fungal cultures than in control experiments without fungi.

Pinzari et al. (2016) also found that the main mechanism of fungal attack on phlogopite was acidification of the medium. In this case, the cultures were performed in Agar medium, i.e. there was no liquid water in the cultures, and the experiments lasted 30 days. The dissolution of phlogopite was visually apparent, generating grooves, thinning of the mica flakes and total breakdown. Fungal attachment was ubiquitous, and charge contrast imaging (CCI, an SEM 
technique; Robertson et al., 2005) showed interaction between the hyphae and mineral surface (dark contrast of the mineral surface around the hyphae), but no pits could be found after the experiments. Pinzari et al. (2016) proposed that initial pits were later obliterated by the intense dissolution of the flakes by acidification ( $\mathrm{pH}$ of the Agar after the experiments ranged from 5.2 to 6.4). They carried out their experiments with three fungal strains, Alternaria tenuissima, Cladosporium cladosporioides and Stilbella sp. Statistical analysis of the chemical data (SEM-EDS) of the weathered phlogopite flakes discriminated between the weathering activities of the three fungal species. In other words, the chemical composition of the weathered flakes was significantly different for each fungal strain. This is an interesting result that opens the future possibility to recognize the present or past presence of specific types of fungi in mineral substrates, including fossil specimens. Pinzari et al. (2016) observed that the weathering of phlogopite in places suggested in situ cation rearrangement and loss producing Al-rich smectite. Thus, a first alteration stage, where acidic conditions were mild, in the process of dissolution, was apparently the transformation from phlogopite to Al-rich smectite.

Wei et al. (2012) carried out a similar experiment in malt extract agar (again, with no liquid water) culturing the fungus Aspergillus niger on muscovite for up to 168 days. After the experiments, the flakes showed signs of corrosion on the surfaces where contact between the hyphae and the biotite took place. They did not perform chemical analyses of the altered muscovite. Muscovite dissolution was much less intense than in the experiments of Pinzari et al. (2016), even though the experiments of Wei et al. (2012) were much longer (168 vs. 30 days of Pinzari et al., 2016), which is mainly due to the greater resistance of muscovite than phlogopite to dissolution. Interestingly, Wei et al. (2012) found areas with a rough surface surrounding the dissolution channels which bear similarity to the areas with different contrast surrounding hyphae in the experiments of Pinzari et al. (2016). These areas in both experiments may represent slight alteration produced by the diffusion of fungal secretions. A companion experiment by Wei et al. (2012) consisted of the incubation of muscovite in a garden soil for $\sim 4 \mathrm{y}$. At the end of the experiment the mica flakes were coated with a biofilm. Investigation of the muscovite surface showed: significant attachment of fungi and bacteria; general deterioration of the surface; some channels, possibly caused by fungal contact attack; and a large amount of mineral debris, probably derived from mica weathering. The two experiments of Wei et al. (2012) suggested that: (1) the contact dissolution mode is initially stronger and is manifested earlier than the noncontact mode; and (2) given enough time, non-contact dissolution progresses and can obliterate the marks of contact dissolution. In addition, as dissolution proceeds and the surface of mica becomes rougher, it becomes increasingly difficult to discover contact dissolution marks.

The experiment of Lian et al. (2008) allowed further comparison between biological and abiotic weathering and between contact and non-contact weathering mechanisms. They placed crushed shale (particles of $<37 \mu \mathrm{m}$ in diameter) in liquid cultures with Aspergillus fumigatus, a thermophilic fungus. The shale contained two main K-bearing minerals, K-feldspar and illite. Some of the experiments allowed direct contact between the fungus and the shale. In other experiments the shale was placed in a porous bag $(0.22 \mu \mathrm{m}$ pore size) so no direct contact with the fungus was possible, and the culture was shaken. The authors adjusted the $\mathrm{pH}$ of the control experiments according to the measurements in the biological experiments as they progressed. The Lian et al. (2008) investigation hinged on the measurement of $\mathrm{pH}$ and $\mathrm{K}$ concentration in the solutions. As no other cations were analysed, their results may be due to simple K release from illite and/ or to feldspar and illite dissolution. They found that $\mathrm{K}$ release was always 3-4 times higher in contact than in non-contact experiments, and that biological experiments released 8-40 times more $\mathrm{K}$ than the controls. The $\mathrm{pH}$ reduced gradually from 6.4 to 3.1 over the 30 days of the experiment. The calculated release rate of $\mathrm{K}$ correlated positively with $\mathrm{pH}$ in the experiments where fungi and shale were in contact, while no correlation was apparent in the experiments where there was no contact between the shale and the fungus. This result apparently contradicts the suggestion that acidification was the mechanism of $\mathrm{K}$ release. Lian et al. (2008) suggested that $\mathrm{K}$ release was promoted by three mechanisms: (1) organic complexation by soluble ligands; (2) adsorption on biopolymers; and (3) mechanical forces. Lian et al. (2008) warned against an overly simplistic view of mineral weathering by fungi based mainly on acid attack. The lack of data on cations released other than of $\mathrm{K}$ leaves us with an unspecified main K-release process between mineral dissolution and cation exchange in illite layers. This complicates the interpretation. Lian et al. (2008) found some protuberances $(\sim 1 \mu \mathrm{m})$ within hyphae that they analysed using SEM-EDS and these were interpreted as ingested pieces of mineral. 
In a different type of experiment, Bonneville et al. (2011) investigated the effect of a single hypha of Paxillus involutus in contact with the basal plane of a biotite flake. The mycorrhizal fungus was growing in symbiosis with Pinus sylvestris, a pine tree species. The experimental set up was arranged for the investigation of contact dissolution only. Boneville et al. (2011) used microscopic techniques and measured $\mathrm{pH}$ values of between 5.8 and $<4.6$ at the hypha-biotite contact, as well as extensive removal $(50-85 \%)$ of all cations except $\mathrm{Si}$ in the interaction volume, which reached up to $20-30 \mathrm{~nm}$ deep in the mica. This study used SEM with focused ion beam to eliminate the layers of altered biotite and to measure the composition through this alteration layer. Those authors concluded that biotite weathering was a combination of local acidification, bio-mechanical forcing and uptake of leached cations by the fungus cells.

Hopf et al. (2009) investigated the dissolution of powdered biotite by both bacteria (Bacillus subtillis, Shwanella putrefaciens and Streptomyces acisdiscabies) and a fungus (Schizophyllum commune) in batch experiments. The $\mathrm{pH}$ of the starting solution was set at 9.5 and there was a general tendency towards $\mathrm{pH}$ decrease during the experiments, with the values scattered between 9.7 and 8.3. Hopf et al. (2009) found that the dissolution rate of the biological experiments, based on $\mathrm{Si}$ release, was similar to those of the control inorganic experiments, although $\mathrm{K}$ was released more quickly in biological experiments and $\mathrm{K} / \mathrm{Si}$ and $\mathrm{Mg} / \mathrm{Si}$ ratios were higher in biological tests.

Balland et al. (2010) conducted experiments with a set of ten bacteria isolated from soils that were inoculated individually onto biotite and phlogopite with the goal of investigating how the bacterial diversity was reflected in the rate and mode of mica dissolution. They based their investigation on $\mathrm{Fe}$ release and the type and concentration of organic acids generated by the bacteria. Their experiments were conducted in microplate wells $(300 \mu \mathrm{L})$ and lasted only 3 days because after this period there were drastic changes in the bacterial metabolism due to consumption of their $\mathrm{C}$ sources. The $\mathrm{pH}$ of their microsuspensions decreased from 6.5 to $5-3$ in the three days. Abiotic control experiments were performed using organic and nitric acids. The biotic experiments produced $\mathrm{Fe}$ release rates similar to those of the control experiments with organic acids, but $2-3$ times higher than those with nitric acid. Balland et al. (2010) assumed that the two main processes promoting $\mathrm{Fe}$ release were acid dissolution and $\mathrm{Fe}$ complexation in solution. They modelled the Fe release rate using a two-term expression with proton and ligand concentrations as the corresponding variables. Their model reproduced successfully the rates of Fe release in many of the experiments. Three domains were found in their weathering reaction: (1) at $\mathrm{pH}<3$, only acid attack occurred; (2) at $\mathrm{pH}$ between 3 and 4-5, ligand- and proton-promoted $\mathrm{Fe}$ release occurred; and (3) at $\mathrm{pH}$ $>4-5$, Fe immobilization as $\mathrm{FeOOH}$ took place, which was another factor promoting Fe release. The different bacterial strains used the three mechanisms of $\mathrm{Fe}$ release in different proportions, which allows us to establish bacterial groups with different weathering strategies. The strategies were different for each of the mica types, i.e. the proportion of mechanisms for $\mathrm{Fe}$ release used by each bacterial strain were different for biotite and phlogopite, with a greater contribution of complexation for biotite and a larger contribution of $\mathrm{FeOOH}$ precipitation for phlogopite. Phlogopite was weathered more efficiently than biotite, probably because of crystal-chemical differences. These results exemplify the variable dissolution strategies of bacteria and their dependence on the mineral substrate. Balland et al. (2010) also found that bacteria isolated from soil horizons deficient in $\mathrm{C}$ (lower soil horizons) were more efficient at dissolving mica than the bacteria isolated from C-rich horizons (top horizons). Presumably, this is due to a greater efficiency of bacteria from C-poor soil horizons to generate the organic acids and ligands that will promote release of $\mathrm{Fe}$.

As fungi, bacteria tend to attach to mineral surfaces and they can also produce local dissolution. The experiment of Song et al. (2007) illustrated the fact that bacteria select the mineral surface to which they attach. Song et al. (2007) placed chips of two types of polished granite in liquid cultures of Bacillus subtilis and incubated them for 30 days. They observed that bacteria attached to the granite and caused etching. More and wider dissolution pits were observed in the bacterial experiments than in the control experiments. Bacteria caused etching preferentially in plagioclase, followed by K-feldspar and quartz, and least of all in biotite. It is not clear why all minerals were preferred over biotite, which has more nutrients $(\mathrm{Fe}, \mathrm{K}, \mathrm{Mg})$. The authors suggested that the surface conditions are important and that the biotite surface may have been the least appropriate for attachment. The $\mathrm{pH}$ of the solutions increased from the original value of 6 to $>7$. More information about bacterial attachment was provided in the experiments by Barker et al. (1998) who cultured biotite sand and groundwater bacteria in 
batch reactors with water. The $\mathrm{pH}$ of the solution (different for each strain) typically increased. Silicon, $\mathrm{Al}$ and $\mathrm{Fe}$ in biotic experiments were released by up to two orders of magnitude above those of the controls. Bacteria colonized all types of surfaces often preferentially along steps and biotite edges. In some cases the cells attached directly and in others through EPS polymers. The surfaces where bacteria attached, in either way, appeared more etched than those surfaces which were uncolonized. One of the strains formed large microcolonies in outer basal surfaces and in secluded spaces in the cleavages at the flake edges. This allowed Barker et al. (1998) to measure the $\mathrm{pH}$ gradient (radiometric $\mathrm{pH}$-sensitive fluorescence) from outer areas, with circum-neutral $\mathrm{pH}$, to these secluded pores, where $\mathrm{pH}$ reached 3-4. Barker et al. (1998) stressed that both cell walls and EPS polymers enhanced biotite weathering. The preferential attachment to steps and rough edges may be due to better adherence and/or to the easier dissolution of phyllosilicate edges than basal planes (e.g. Kalinowski \& Schweda, 1996; Zysset \& Schindler, 1996).

Cell attachment is related to the bacterial strategy for acquiring nutrients from the mineral. Kuhn et al., (2013) carried out experiments of Pseudomonas mendocina on montmorillonite (SWy-2), in solution media, to investigate Fe release by the bacterium. Tests were carried out allowing contact between the bacteria and montmorillonite and separating both by dialysis membranes. The bacterium used two Fe-extraction strategies according to the type of test. The first was the release of siderophores, which did not require contact with the montmorillonite particles. The second strategy was Fe reduction (which causes smectite dissolution) and required contact with montmorillonite because $P$. mendocina does not produce secreted reductants. This investigation shows the flexibility of bacterial strategies in response to the environment. The total dissolution of montmorillonite was minimal as indicated by analysis of $\mathrm{Si}, \mathrm{Al}$ and $\mathrm{Fe}$ in the solutions.

\section{ENERGY SOURCES AVAILABLE IN PHYLLOSILICATES}

Of all the recognized organic and inorganic compounds and elements that can be used as electron donors and recipients in the respiration process of microorganisms (e.g. Nealson \& Popa, 2005), Fe, Mn and ammonium are the only entities that can be found in phyllosilicates (Fig. 3). Hydrogen is related closely to serpentine as it is produced in the serpentinization reaction mentioned above, but this hydrogen is not a component of the phyllosilicate. Reduction of $\mathrm{Fe}^{3+}$ in phyllosilicates is a typical process used by microorganisms as an electron sink. Dong et al. (2009) recently reviewed microbial $\mathrm{Fe}$ reduction in phyllosilicates and the reader is referred to this article for a detailed discussion of this process and implications (although the title of the article by Dong et al., 2009 suggests a wider review, it is, in fact, focused exclusively on microbial Fe reduction). Some of the most relevant conclusions are indicated here. The largest groups of microorganisms with phyla or groups involving Fe reduction in their respiration process are bacteria and archaea, although some fungi also do it (Ottow \& Von Klopoteck, 1969). The extent of Fe reduction in phyllosilicates may be important because it partially controls certain physical and chemical properties of soils and sediments, such as particle flocculation, surface area, interlayer swelling, hydraulic conductivity, cation exchange capacity (CEC) and reactivity. Investigation of smectite has shown that $\mathrm{Fe}$ reduction causes an increase in layer charge and thus greater CEC values and smaller $d$-spacing values due to the greater attraction between interlayer cations and layers. In the presence of $\mathrm{K}$ this process can lead to smectite illitization in surface environments and cooperate to smectite illitization in burial diagenesis, as described above. Reduction of $\mathrm{Fe}$ in swelling phyllosilicates in soils may thus be detrimental to soil fertility because it would decrease water retention and the capacity to exchange inorganic nutrients (Dong et al., 2009). At the same time it may have the positive effect of decreasing organic sequestration in the interlayer space of smectite or vermiculite and maintain organic matter available to microbes. The effect on soil fabric is also important although it is not evident how it is affected by $\mathrm{Fe}$ reduction in phyllosilicates. The factors to consider in relation to soil fertility and health are multiple and interconnected and it is not possible to establish cause-effect links $a$ priori.

Iron reduction has been studied mainly in montomorillonite and nontronite but also in vermiculite, illite, chlorite, illite-smectite and palygorskite. Smectite, both montmorillonite and nontronite, is the phyllosilicate where $\mathrm{Fe}$ is reduced more quickly and to a greater extent. Iron is most difficult to reduce in illite, followed by chlorite. The reasons for this are the expandability and the smaller particle size of smectite, which increases the accessibility of structural $\mathrm{Fe}$ for electron transfer (Dong et al., 2009). Note that structural $\mathrm{Fe}^{2+}$ in smectite is oxidized spontaneously to $\mathrm{Fe}^{3+}$ to a large extent in contact with the atmosphere 


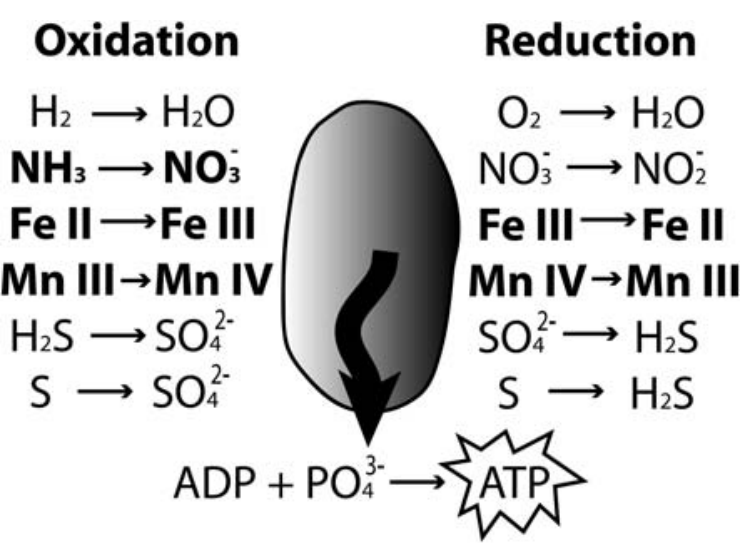

FIG. 3. Some of the several oxidation-reduction reactions used by microorganisms for respiration. The redox process of elements or compounds found in clay minerals are shown in bold. The energy involved in the electron transfer is typically stored finally in the chemical bond of adenosine triphosphate (ATP) generated by the addition of a phosphate group to adenosine diphosphate (ADP).

(Neumann et al., 2011; Morrison et al., 2013), whereas $\mathrm{Fe}^{2+}$ in non-expandable phyllosilicates (such as glauconite, illite, biotite, chlorite) is stable. The same ease of electron transfer operates in Fe reduction and oxidation processes. For the reduction process some prokaryotes need to contact the surface of the mineral (Luef et al., 2013) whereas others generate electron shutters that transfer the electrons to $\mathrm{Fe}$ in the mineral (Jaisi et al., 2005). These electron shutters are soluble substances with functional groups that can accept and donate electrons easily and reversibly, and thus are able to carry out their function multiple times. If electron shutters are placed in the experimental medium, contact between bacteria and the mineral may not be necessary (Jaisi et al., 2005) and, typically, Fe reduction is accelerated and proceeds further (Dong et al., 2009). The possibility of using one or the other Fe-reduction mechanisms is specific to prokaryotic strains. Recently, it has been proposed that some Fereducing bacteria, that do not produce electron shutters, attach $\mathrm{FeOOH}$ to their cells in order to use this $\mathrm{Fe}^{3+}$ when in planktonic form (living outside biofilms) and detached from minerals (Luef et al., 2013). The existence of Fe-oxide attachments to Fe-reducing bacteria is very common (Dong et al., 2009) although it is not known in which cases and to what extent such situations are intended for the benefit of the bacteria or accidental and potentially harmful.

Microorganisms generate organic substances of many types and become decaying organic matter when they die. This organic matter must have an effect on the ability of prokaryotes to reduce Fe. Organic substances may help the process of reduction, as in the case of the electron shuttle substances, or they may interfere with it in many ways. Biofilms can facilitate the process by causing adherence of the prokaryotes to mineral surfaces (Luef et al., 2013) or by precipitation of FeOOH on EPS (Dong et al., 2009). Organic matter in the interlayer space of smectite and vermiculite also needs to be considered as the interlayer region appears to be a path for electron transfer (Morrison et al., 2013). The presence of toluene intercalated into nontronite was found to inhibit bacterial $\mathrm{Fe}$ reduction by Shewanella putrefaciens, perhaps because it blocked the electron-transfer process or because it was toxic to the bacteria, whereas cysteine intercalation enhanced Fe reduction (Zhang et al., 2007b). This finding illustrates the complex effect that organic matter may have on the process in natural settings.

Reduction of structural $\mathrm{Fe}$ may result in mineral dissolution, total or partial, because the change of electric charge destabilizes the mineral. Metal reduction was mentioned above as a microbial mechanism to dissolve minerals and obtain nutrients. There is experimental evidence for this Fe-reduction-driven mineral dissolution of phyllosilicates (Dong et al., 2009). All sets of conditions mentioned above that favour extensive $\mathrm{Fe}$ reduction will tend to cause mineral dissolution.

Field investigation of Fe reduction in phyllosilicates is complicated by the large number of variables involved. An intermediate step towards the investigation of natural settings is the use of complex systems in which certain variables in the natural system are maintained constant or simulated. Of these variables, the microbial diversity is the most difficult to reproduce and the mineral diversity 
the easiest. An experimental combination of Pseudomonas bacterium strains reduced $10-24 \%$ of structural $\mathrm{Fe}^{3+}$ in a mixture of phyllosilicates (illite, kaolinite, chlorite, smectite, vermiculite and illitesmectite) from clayey till samples where the original proportion of structural $\mathrm{Fe}^{2+}$ was $10 \%$ (Ernstsen et al., 1998). The authors found that particle size (coarse vs. fine) and the original amount of $\mathrm{Fe}^{2+}$ were important controls of the extent of bacterial $\mathrm{Fe}$ reduction. Apparently, the greater the original $\mathrm{Fe}^{2+}$ content the more energy is necessary to further reduce structural $\mathrm{Fe}$ and the less the additional reduction. The effect of particle size in this experiment was complicated because it may have been linked to mineralogy and $\mathrm{Fe}$ content in the several minerals in the different particle-size pools. Iron reduction in sediments where re-oxidation takes place naturally may be a renewable electron sink that can be used repeatedly by microorganisms (Ernstsen et al., 1998). For this, however, Fe reduction must not proceed so much that the phyllosilicate becomes unstable and dissolves or Fe is partially lost in every cycle. Neither should it happen that reduction produces illitization of smectite (because $\mathrm{Fe}^{2+}$ in illite is not re-oxidized by atmospheric oxygen; Dong, 2012). Interestingly, however, microbial Fe reduction is increasingly inhibited as it progresses. The inhibition is due to several possible causes such as: release of $\mathrm{Fe}^{2+}$ which attaches to mineral and cell surfaces and blocks electron transfer; accumulation of reaction products which also blocks further reaction; and the change in the energy required for further Fe reduction (Dong, 2012).

Microbial $\mathrm{Fe}$ reduction in marine sediments is also important. It was discussed above in the context of glauconite and verdine-facies formation but seems not to be confined to them only. Iron reduction in smectite not leading to mineralogical changes (illitization or glauconization) has been hypothesized (Dong et al., 2009) in relation to colour changes in marine sediments ( $\tan$ to green). In principle, the Fe-reduction process in this case is the same as in that of glauconite maturation but environmental conditions, such as total $\mathrm{Fe}$ available for reduction (and thus layer charge after reduction) and $\mathrm{K}$ or $\mathrm{NH}_{4}$ availability for exchange and closing of the illitic layers, modify the reversibility of the process. If no illite layers are generated, $\mathrm{Fe}^{2+}$ can be re-oxidized if environmental conditions change, allowing oxygenation of the sediment or precluding the action of Fe-reducing prokaryotes.

Iron can also be oxidized to $\mathrm{Fe}^{3+}$ as a way of obtaining energy. The process is also common, especially with Proteobacteria (Hedrich et al., 2011) but the corresponding metabolism is less understood than that of Fe-reducing prokaryotes (Emerson et al., 2010) and less work has been carried out with phyllosilicates (Dong, 2012). One of the reasons for this lack of experimental work may be that phyllosilicates containing $\mathrm{Fe}^{2+}$ are less accessible to microbial action due to their lack of expandability and larger particle size. Smectite and vermiculite, where Fe can be accessed more readily, usually contain $\mathrm{Fe}^{2+}$ as a trace or minor component only. It is not known whether Fe oxidation in phyllosilicates is a common process used by, as yet, uninvestigated prokaryotes.

Manganese is much less abundant in phyllosilicates than $\mathrm{Fe}$. Although both $\mathrm{Mn}$ reduction and oxidation are known to be mediated by prokaryotes as part of their respiration cycle, to the best of the present author's knowledge, no information is readily available on the use of $\mathrm{Mn}$ in phyllosilicates for microbial respiration. Fungal strains have been found capable of oxidizing $\mathrm{Fe}$ and $\mathrm{Mn}$, possibly as a means of weathering minerals for nutrient extraction (de la Torre \& Gomez-Alarcon, 1994; Thompson et al., 2005). Again, no information is available about this process taking place on phyllosilicates. Ammonia oxidation to nitrate is carried out by nitrifying bacteria and archaea. The nitrifying bacteria are apparently a narrow taxonomic group and found in large numbers only where ammonia is abundant as a result of protein decomposition, i.e. where large amounts of biological material decay. Nitrifying archaea have been discovered more recently. In principle, these microbial groups could use ammonium from mica and illite for their respiration. Gerbl et al. (2014) found nitrifying prokaryotes in a subsurface spring in the Alps and considered the possibility of interlayer ammonium in mica from the granite and gneiss as the ammonium source. Interlayer ammonium may also be used not for respiration but as a nutrient. Landeweert et al. (2001) suggested that ectomycorrhizal fungi can transfer this ammonium to plants after leaching mica or illite, which reduces the reliance on atmospheric $\mathrm{N}$ fixation for plant nutrition. Future research will probably confirm the use of interlayer ammonium and structural Mn for microbial respiration because life seems to be able to develop the use of every possible energy and nutrient source.

\section{EFFECTS OF MICROORGANISMS ON CLAY MINERALS OTHER THAN FORMATION, DISSOLUTION OR WEATHERING}

Apart from exchange of interlayer cations, leaching, dissolution and precipitation, microorganisms can 
have other effects on clay minerals that modify in some way their physical or chemical characteristics and change their properties. One obvious type of such changes relates to the modification of the hydration state in the interlayer and the intercalation of organic compounds. These changes are very likely in the organic-rich environment of the biofilm. Alimova et al. (2009) mixed hectorite and Pseudomonas syringae in a liquid medium, which evolved into a polysacchariderich biofilm within 7 days. The original hectorite had a $d$ spacing of $15 \AA$, corresponding to a 2 -water layer content. Contact with the biofilm caused the 001 peak first to shrink to a $d$ spacing of $12.6 \AA$ within $2-72 \mathrm{~h}$ of incubation, and then to generate a very wide peak that had three components at $18.4,14.1$ and $10.1 \AA$. The 001 peak corresponding to $18.4 \AA$ was very wide and possibly enveloped several peaks with different $d$-spacing values. The first contraction is consistent with a partial dehydration of the interlayer space which may have been caused by hydrophilic sites in the biofilm in close contact with the smectite particles. The expansion to $18.4 \AA$ was caused by intercalation with organic molecules. This intercalation was very incomplete and/or chaotic, given the range of $d$-spacing values found. Treatment of the intercalated smectite to remove the organic matter (with Clorox) resulted in the loss of the 18.4 and $10.1 \AA$ peaks, from which fact the authors deduced that the $10.1 \AA$ peak was also due to organic intercalation. The present author believes that this is not possible because the corresponding organic molecules would have been very small in order to fit into the almost totally collapsed interlayer space. The $10.1 \AA$ layers corresponded to dehydrated hectorite. Contact with the biofilm generated a complex system of intercalated layers and layers with a variable degree of hydration, possibly also coated by organics. The organic-removal treatment displaced the organics from the expanded interlayers and coatings (perhaps incompletely) and partially restored the hydration state of the hectorite $(\sim 14 \AA)$.

Alimova et al. (2009) concluded that smectite is a potential storage of organic $\mathrm{C}$ in or near biofilms, as was discussed above. If the intercalated organic $\mathrm{C}$ is stable, the chemical properties of smectite can change, especially the CEC. Smectite can also transport organic $\mathrm{C}$ to the deeper crust during burial. When expelled from the interlayer, due to increased pressure, the organic $\mathrm{C}$ can migrate and react to form new compounds. It would be interesting to investigate whether C-rich smectite follows different diagenetic routes from smectite containing no or minor organics, in both burial and surface settings. Differences might be due to: (1) changes in $\mathrm{pH}$ produced by the organics, possibly enhancing dissolution; (2) protection of smectite from chemical changes by polymeric coatings; (3) complexation of some cations and their partial retrieval from the parent smectite and newly formed phyllosilicates; (4) enhancement of microbial activity that may then affect the diagenetic reactions (as in smectite illitization discussed above); and (5) exclusion of water and slow down of diagenetic reactions. Only a few of these possibilities have been explored to date, and none extensively (Small, 1994; Berger et al., 1997; Zhang et al., 2007b).

Perdrial et al. (2009) investigated the effect of the bacterium Shewanella putrefaciens on montmorillonitic bentonite (SWy-1, also known as MX80) and nontronite in two environments, in water dispersion (60 days) and in pressed pellets (up to 21 days). The pellets simulated the confinement of bentonite in underground nuclear waste repositories. The batch experiments showed associations of biofilms with the clay particles. For nontronite, there appeared also Si-rich gels caused by nontronite dissolution. Montmorillonite was less chemically affected, possibly because of the lower Fe content. Iron in smectite may trigger mechanisms of $\mathrm{Fe}$ extraction by microorganisms or, simply, montmorillonite is more difficult to dissolve than nontronite. In addition, accessory minerals in the bentonite such as feldspar, calcite and pyrite, absent from nontronite, may have contributed nutrients more easily extractable than from montmorillonite. In the pellets, the bacterium caused a marginal increase in water adsorption by the montmorillonitic bentonite, both in the interlayer space and pore space.

Müller (2009) prepared experiments with vermiculite and the bacterium Pseudomonas fluorescens and several genetic derivative strains with the aim of investigating whether these closely related bacteria would interact differently with ground vermiculite. The experiments took place in a shaken suspension and lasted 14 days. The bacteria were found to attach to the vermiculite particles. Two of the strains reduced the vermiculite particle size slightly as measured with light scattering, and the others increased it, presumably by particle aggregation. All strains reduced the specific surface area (BET) of vermiculite. There were small changes in the measured layer charge and CEC that cannot be interpreted readily. The $d$ spacing of the 001 peak changed from $14.1 \AA$ to a range of values between 14.6 and $12.9 \AA$, typically less than the original $14.1 \AA$. In three cases a double peak was generated. These changes were due to interlayer cation exchange, where Na partially replaced $\mathrm{Mg}$ and $\mathrm{K}$. This 
exchange was caused by the nutrient medium because it also took place in the control experiments, although the several bacterial strains modified the extent of the exchange in different fashions. Dissolution of vermiculite took place at trace levels only. Müller (2009) measured the amounts of $\mathrm{Fe}, \mathrm{Mn}$ and a large group of trace metals in the vermiculite samples after the experiments. In most cases the levels present were less than both the original vermiculite and vermiculite in the control experiments. These results were interpreted to indicate cation uptake by the bacteria. The metal contents in the weathered vermiculite varied depending on the strain. Overall, the changes induced by the bacteria in such a short period were related mainly to the interlayer cations and hydration state and were probably reversible. Note however, that the strains, all of them closely related genetically, induced different changes.

\section{IMPLICATIONS AND CONCLUSIONS}

Reading about mineral-microbe interactions may produce a feeling of uneasiness because so many articles report apparently inconsistent results. Microorganisms accelerate, retard or have no effect on mineral weathering. They dissolve minerals mainly by contact mechanisms or by non-contact mechanisms, and so on. Evidently, these studies deal with a very large number of variables, some obvious, some hidden. Microbial species, mineral substrate, environmental conditions, nutrient content of the medium, presence or absence of water, etc. are visible variables that may control hidden variables related to the expression of microbial genes. Other hidden variables may be the trace composition of minerals, aspects of the physical interaction between minerals and microbes of which we currently know nothing or the effect of microbial metabolites on the microorganisms themselves. If we consider the investigation of the cooperation of a few microbial species or of natural systems, the number of hidden variables grows enormously. The natural result is the present situation that resembles that of a diver in dark waters with a torch that illuminates only partially shapes that go past or objects that are too large for the light to show enough of them to be recognized. With this situation in mind, some issues are listed below that, in the present author's opinion, deserve special attention because they point towards questions that can open or develop fruitful paths of investigation.

The majority of authors seem to believe that, overall, microorganisms enhance mineral weathering. However, logical thinking and results from some studies (of which some examples have been provided above) suggest that whether microorganisms promote weathering or protect minerals depends on the system. As indicated above, our experiments are biased towards short times and unrealistically simple microcosms. The long-term effects of microbial interaction with minerals may be quite different. Moreover, experiments are designed to observe mineral dissolution, with well known, aggressive microorganisms and in systems that rely strongly on minerals for nutrient sources. I am not aware of any experiment designed to observe mineral protection by microorganisms. Also, some of the studies discussed above have suggested that microbes weather minerals selectively or in a controlled way in order to preserve their nutrient sources. This may result in a protection effect because the microbial weathering rates become slower than the inorganic ones. Such types of controlled weathering could be carried out very efficiently where there is cooperation between microbial species and mutual reliance between them for nutrient acquisition.

Microorganisms develop systems to either generate microenvironments that they can control, or to live in those already existing. This is the case with the biofilms but also with the mineral-particle aggregates that are found in soils and in sediments underwater, with endolithic environments both in land and marine habitats, and with microorganisms living deep underground where lithostatic pressure reduces porosity and microbes necessarily live in small volumes surrounded by mineral grains. In all this vast variety of environments, 'encapsulation' is taking place. Microorganisms enclose themselves in mineralbiofilm systems where the chemistry is controlled not only by the bulk water (i.e. outside the biofilm) composition, but also by the mineral surfaces and microbial activity. The activity of microorganisms modifies the inorganic conditions and generates the biological effect on the rock. This concept can expand even more because the direct contact or cells or EPS polymers with mineral surfaces is also a way of encapsulation. The immediate proximity of cells and EPS with the mineral generate conditions that are different from the bulk environment and even from other parts of the biofilm. Examples have been provided of extremely low $\mathrm{pH}$ values measured at the contact between microbial cells and minerals and of the steep $\mathrm{pH}$ gradients measured moving away from the cells. The physical pressure of hyphae adds to the chemical effects of this proximity to generate local physico-chemical environments which are very different from the bulk. 'Encapsulation', however, is not 
identical to 'aggressive environment', but to 'modified environment'. The modified environment may be more aggressive to the mineral surface, less aggressive to it or simply change the way of weathering and the composition and or mineralogy of the products. Polymeric coatings can protect mineral surfaces, biofilms may generate stable environments in equilibrium with weathered mineral surfaces, etc. Whatever the effect, encapsulation is important and necessary in many cases for the microorganisms to be able to modify effectively the inorganic environmental conditions and leave their footprint on the evolution of the mineral surfaces, soils and sediments. Without encapsulation, the chemical secretions of the microorganisms would be diluted immediately in the environment and become ineffective for their purpose.

Reverse weathering (formation of illite-like minerals in near-surface sediments) is an indirect result of microbial activity. In mangrove forests, $\mathrm{Fe}^{2+}$ generated by microbial action and organic decay reacts with kaolinite and smectite to produce mixed-layer kaolinite-smectite and illite-smectite with increasing $\mathrm{Fe}$ content. The structural $\mathrm{Fe}$ of such clay mineral phases is further reduced by microbial action, which together with $\mathrm{K}$ and $\mathrm{NH}_{4}$ fixation results in the formation of Fe-illite or glauconite. These reactions demonstrate that microbial action is not only associated with weathering, as tends to be considered, but also with the opposite process. More research is needed to investigate the extent of such processes taking place not only in coastal and shallow waters, but also in deep-sea sediments (Baldermann et al., 2015), which adds an enormous area where reverse weathering may be taking place. The resulting effect would certainly be of global relevance for mineralogical and element cycles.

Microbes have the potential to use several strategies of mineral attack to obtain nutrients. It stands to reason that the mechanisms are used according to their energy and nutrient requirements, from those which consume less to more. If the mechanism used is not successful, there will be an escalation of its intensity or a change to another mechanism until the required rate of nutrient mobilization is reached. Different minerals contain different metal nutrients, in different proportions and bonded to the mineral lattices with different strengths. Soil or sediment fabric also may control the accessibility of the mineral surfaces, and the nature of these mineral surfaces controls the ability of microorganisms to attach to them. These variables are a positive control of microbial activity in order to obtain their necessary mineral nutrients and they contribute to the evolution of microbial species. Moreover, it was indicated above how clay minerals, in particular, facilitate gene transfer between microbial species, which is a contribution to evolution that is even more direct and effective. As there is such a mutual modification of minerals and microorganisms, we can talk of a coevolution of microorganisms and rocks. These interactions extend much further, via both the rocks and microorganisms, to the hydrosphere, atmosphere and all living organisms. The evolution of Life is in fact a coevolution with the Earth. The investigation of mineral-microbe interaction is contributing an important element of how this co-evolution took and continues to take place.

One of the big challenges in the investigation of the effects of microorganisms on the evolution of the Earth's surface is to discover their activity in the geological record. Typically, biologically generated mineralization or alteration marks are difficult to identify unambiguously in ancient rocks. Isotopic signatures are helpful in the case of microbial mineralization but weathering does not have such an advantage. The morphology of borings into volcanic glass and any organic remains in them are criteria used to identify microbial action in basalt (Staudigel et al., 2008). Characteristic leaching of trace elements, produced by the action of the organic acids or chelating agents, has been proposed as a possible way of identifying weathering by microorganisms (Hausrath et al., 2009). Further investigation is necessary to establish more, wider and better criteria. The modification of conditions in the biofilms may generate weathering products, clay minerals among them, with composition and mineralogy in contrast to those generated prevalently by the inorganic environmental conditions. As a matter of fact, clay minerals are used to investigate past climates and environments. Perhaps the moment will come when it will be possible to spot biologically modified environments within the general environment generated by climate, geology and hydrologic conditions.

Progressing one step further, we can consider the possibilities of recognizing the activity of specific microorganisms or groups of them on rocks, soils and sediments, present and past. For example, it would be desirable to be able to determine that a specific signature in a fossil soil was produced by a specific type of fungi where no remains of the fungi exist. In this way not only could the biological activity be assessed in terms of quantity and quality but the development of specific phyla and genus could be traced back through the geological record. Relatively recent rocks, soils and sediments that have lost their 
biological content could tell the tale of what sorts of microorganisms inhabited and shaped them. The statistically distinguishable footprints of three individual fungal species on phlogopite, presented above, are a very preliminary but promising step in this direction.

In all these issues clay minerals play a central role. They are the most stable forms of silicates on the Earth's surface, where most of the biological activity takes place. They are also a typical product of the action of microorganisms on silicate rocks. They are key players in the physico-chemical interaction between the microorganisms and their environment. But clay minerals are also extremely complex and thus more difficult to study and interpret their processes than it is for other minerals in the context of interaction with microorganisms. Perhaps for this reason there exists certain bias and they are under-represented in these studies. There will be no complete understanding of the mineral-microbe interaction if clay minerals are not fully included in the picture, and it is exciting that we, clay scientists, have the opportunity to contribute to this task.

\section{ACKNOWLEDGEMENTS}

J. Cuadros thanks the European Community for the opportunity to work on mineral-microbe interactions in the context of two Marie Skłodowska Curie fellowships Bio-Clays (2009-2011) to B. Afsin and Bio-Strategies (2015-2017) to A. Perez-Sanz. He thanks his two fellow recipients of these grants and other collaborators during these and other studies for their contributions to and help with work on the topic: M. Ardakani, C. Ascaso, D. Baussa, W. Dubbin, J. Duckett, P. Jadubansa, A. Jungblut, P. Kenrick, C. Mavris, R. Mitchell, R. Napoli, F. Pinzari, S. Pressel, B. Spiro and J. Wierzchos. A. Jungblut and F. Pinzari also read this contribution and provided helpful comments. The anonymous reviewer is acknowledged for detailed review and discussion.

\section{REFERENCES}

Adamo P. \& Violante P. (2000) Weathering of rocks and neogenesis of minerals associated with lichen activity. Applied Clay Science, 16, 229-256.

Adeyemi A.O \& Gadd G.M. (2005) Fungal degradation of calcium-, lead- and silicon-bearing minerals. BioMetals, 18, 269-281.

Alimova A., Katz A., Steiner N., Rudolph E., Wei H., Steiner J.C. \& Gottlieb P. (2009) Bacteria-clay interaction: Structural changes in smectite induced during biofilm formation. Clays and Clay Minerals, 57, 205-212.

Alt J.C. \& Mata P. (2000) On the role of microbes in the alteration of submarine basaltic glass: a TEM study. Earth and Planetary Science Letters, 181, 301-313.

Amundson R., Richter D.D., Humphreys G.S., Jobbágy E. \& Gaillardet J. (2007) Coupling between biota and the Earth materials in the Critical Zone. Elements, 3, 327-332.

Andrade G., de Azevedo A., Cuadros J., Souza Jr, V., Furquim S., Kiyohara P. \& Vidal-Torrado P. (2014) Transformation of kaolinite into smectite and ironillite in Brazilian mangrove soils. Soil Science Society of America Journal, 78, 655-672.

Arocena J.M., Velde B. \& Robertson S.J. (2012) Weathering of biotite in the presence of arbuscular mycorrhizae in selected agricultural crops. Applied Clay Science, 64, 12-17.

Ascaso C. \& Galvan J. (1976) Studies on the pedogenetic action of lichen acids. Pedobiologia, 16, 321-331.

Baldermann A., Warr L., Grathoff G. \& Dietzel M. (2013) The rate and mechanism of deep-sea glauconite formation at the Ivory Coast-Ghana marginal ridge. Clays and Clay Minerals, 61, 258-276.

Baldermann A., Warr L., Letofsky-Papst I. \& Mavromatis V. (2015) Substantial iron sequestration during greenclay authigenesis in modern deep-sea sediments. Nature Geoscience, 8, 885-890.

Balland C., Poszwa A., Leyval C. \& Mustin C. (2010) Dissolution rates of phyllosilicates as a function of bacterial metabolic diversity. Geochimica et Cosmochimica Acta, 74, 5478-5493.

Balogh-Brunstad Z., Keller C.K., Dickinson J.T., Stevens F., Li C.Y. \& Bormann B.T. (2008) Biotite weathering and nutrient uptake by ectomycorrhizal fungus, Suillus tomentosus, in liquid-culture experiments. Geochimica et Cosmochimica Acta, 72, 2601-2618.

Banfield J.F., Barker W.W., Welch S.A. \& Taunton A. (1999) Biological impact on mineral dissolution: Application of the lichen model to understanding mineral weathering in the rhizosphere. Proccedings of the National Academy of Sciences, 96, 3404-3411.

Barker W.W. \& Banfield J.F. (1996) Biologically versus inorganically mediated weathering reactions: relationships between minerals and extracellular microbial polymers in lithobiontic communities. Chemical Geology, 132, 55-69.

Barker W.W., Welch S.A. \& Banfield J.F. (1997) Biogeochemical weathering of silicate minerals. Pp. 392-428 in: Geomicrobiology: Interactions between Microbes and Minerals (J.F. Banfield and K.H. Nealson, editors). Reviews in Mineralogy and Geochemistry, 35. Mineralogical Society of America, Chantilly, Virginia, USA.

Barker W.W., Welch S.A., Chu S. \& Banfield J.F. (1998) Experimental observations of the effects of bacteria on 
aluminosilicate weathering. American Mineralogist, 83, 1551-1563.

Battistuzzi F.U., Feijao A. \& Hedges S.B. (2004) A genomic timescale of prokaryote evolution: insights into the origin of methanogenesis, phototrophy, and the colonization of land. BMC Evolutionary Biology, 4, 44. DOI: $10.1186 / 1471-2148-4-44$.

Belnap J. (2003) The world at your feet: desert biological soil crusts. Frontiers in Ecology and the Environment, 1, 181-189.

Belnap J., Büdel B. \& Lange O.L. (2001) Biological soil crusts: characteristics and distribution. Pp. 3-30 in: Biological Soil Crusts: Structure, Function, and Management (J. Benlap \& O.L. Lange, editors). Ecological Studies series vol. 150, Springer, Berlin.

Benzerara K., Menguy N., Guyot F., Vanni C. \& Gillet P. (2005) TEM study of a silicate-carbonate-microbe interface prepared by focused ion beam milling. Geochimica et Cosmochimica Acta, 69, 1413-1422.

Berger G., Lacharpagne J-C., Velde B., Beaufort D. \& Lanson B. (1997) Kinetic constraints on illitization reactions and the effects of organic diagenesis in sandstone/shale sequences. Applied Geochemistry, 12, 23-35.

Berner E. \& Berner R. (2012) Global Environment: Water, Air, and Geochemical Cycles. Princeton University Press, Princeton, New Jersey, USA.

Bigham J.M., Bhatti T.M., Vuorinen A. \& Tuovinen O.H. (2001) Dissolution and structural alteration of phlogopite mediated by proton attack and bacterial oxidation of ferrous iron. Hydrometallurgy, 59, 301-309.

Boneville S., Morgan D.J., Schmalenberger A., Bray A., Brown A., Banwart S.A. \& Benning L.G. (2011) Treemycorrhiza symbiosis accelerate mineral weathering: Evidence from nanometer-scale elemental fluxes at the hypha-mineral interface. Geochimica et Cosmochimica Acta, 75, 6988-7005.

Brehm U., Gorbushina A. \& Mottershead D. (2005) The role of microorganisms and biofilms in the breakdown and dissolution of quartz and glass. Palaeogeography, Palaeoclimatology, Palaeoecology, 219, 117-129.

Butterfield N.J. (2000) Bangiomorpha pubescens n. gen., n. sp.: implications for the evolution of sex, multicellularity, and the Mesoproterozoic/Neoproterozoic radiation of eukaryotes. Paleobiology, 26, 386-404.

Carson J.K., Rooney D., Gleeson D.B. \& Clipson N. (2007) Altering the mineral composition of soil causes a shift in microbial community structure. FEMS Microbiology Ecology, 61, 414-423.

Chamley H. (1989) Clay Sedimentology. Springer-Verlag, Berlin.

Chen J., Blume H.P. \& Beyer L. (2000) Weathering of rocks induced by lichen colonization - a review. Catena, 39, 121-146.

Chorover J., Kretzschmar R., Garcia-Pichel F. \& Sparks D.L. (2007) Soil biogeochemical processes within the Critical Zone. Elements, 3, 321-326.
Courvoisier E. \& Dukan S. (2009) Improvement of Escherichia coli growth by kaolinite. Applied Clay Science, 44. 67-70.

Cuadros J., Afsin B., Michalski J.R. \& Ardakani M. (2012) Fast, microscale-controlled weathering of rhyolitic obsidian to quartz and alunite. Earth and Planetary Science Letters, 353-354, 156-162.

Cuadros J., Afsin B., Jadubansa P., Ardakani M., Ascaso C. \& Wierzchos J. (2013a) Microbial and inorganic control on the composition of clay from volcanic glass alteration experiments. American Mineralogist, 98, 319-334.

Cuadros J., Afsin B., Jadubansa P., Ardakani M., Ascaso C. \& Wierzchos J. (2013b) Pathways of volcanic glass alteration in laboratory experiments through inorganic and microbially-mediated processes. Clay Minerals, 48, 423-445.

Cuadros J., Andrade G., Ferreira T.O., Partiti C.S.M., Cohen R. \& Vidal-Torrado P. (2017) The mangrove reactor: fast clay transformation and potassium sink. Applied Clay Science, 140, 50-58.

Curry K.J., Bennett R.H., Mayer L.M., Curry A., Abril M., Biesiot P.M. \& Hulbert M.H. (2007) Direct visualization of clay microfabric signatures driving organic matter preservation in fine-grained sediment. Geochimica et Cosmochimica Acta, 71, 1709-1720.

de la Torre M.A. \& Gomez-Alarcon G. (1994) Manganese and iron oxidation by fungi isolated from building stone. Microbial Ecology, 27, 177-188.

de los Ríos A., Wierzchos J., Sancho L.G. \& Ascaso C. (2003) Acid microenvironments in microbial biofilms of antarctic endolithic microecosystems. Environmental Microbiology, 5, 231-237.

Dong H. (2012) Clay-microbe interactions and implications for environmental mitigation. Elements, 8, 113-118.

Dong H., Jaisi D., Kim J. \& Zhang G. (2009) Microbeclay mineral interactions. American Mineralogist, 94, 1505-1519.

Douglas S. \& Beveridge T. (1998) Mineral formation by bacteria in natural microbial communities. FEMS Microbiology Ecology, 26, 79-88.

Dröge M., Pühler A.W. \& Selbitschka W. (1999) Horizontal gene transfer among bacteria in terrestrial and aquatic habitats as assessed by microcosm and field studies. Biology and Fertility of Soils, 29, 221-245.

Emerson D., Fleming E.J. \& McBeth J.M. (2010) Ironoxidizing bacteria: an environmental and genomic perspective. Annual Review of Microbiology, 64, 561-583.

Ernstsen V., Gates W. \& Stucki J. (1998) Microbial reduction of structural iron in clays - a renewable source of reduction capacity. Journal of Environmental Quality, 27, 761-766. 
Etienne S. \& Dupont J. (2002) Fungal weathering of basaltic rocks in a cold oceanic environment (Iceland): comparison between experimental and field observations. Earth Surface Processes and Landforms, 27, 737-748.

Fiore S., Dumontet S., Huertas F.J. \& Pasquale V. (2011) Bacteria-induced crystallization of kaolinite. Applied Clay Science, 53, 566-571.

Frausto da Silva J.J.R. \& Williams R.J.P. (2001) The Biological Chemistry of the Elements: The Inorganic Chemistry of Life, 2nd Edition. Oxford University Press, Oxford.

Gazzè S.A., Saccone L., Ragnarsdottir K.V., Smits M.M., Duran A.L., Leake J.R., Banwart S.A. \& McMaster T. J. (2012) Nanoscale channels on ectomycorrhizalcolonized chlorite: Evidence for plant-driven fungal dissolution. Journal of Geophysical Research, 117, G00N09.

Gerbl F.W., Weidler G.W., Wanek W., Erhardt A. \& StanLotter H. (2014) Thaumarchaeal ammonium oxidation and evidence for a nitrogen cycle in a subsurface radioactive thermal spring in the Austrian Central Alps. Frontiers in Microbiology, 5, Article 225. http:// dx.doi.org/10.3389/fmicb.2014.00225

Grote E.E., Belnap J., Housman D.C. \& Sparks J.P. (2010) Carbon exchange in biological soil crust communities under differential temperatures and soil water contents: implications for global change. Global Change Biology, 16, 2763-2774.

Hama K., Bateman K., Coombs P., Hards V., Milodowski A., West J., Wetton P., Yoshida H. \& Aoki K. (2001) Influence of bacteria on rock-water interaction and clay mineral formation in subsurface granitic environments. Clay Minerals, 36, 599-613.

Hausrath E., Neaman A. \& Brantley S. (2009) Elemental release rates from dissolving basalt and granite with and without organic ligands. American Journal of Science, 309, 633-660.

Heberling C., Lowell R.P., Liu L. \& Fisk M.R. (2010) Extent of the microbial biosphere in the oceanic crust. Geochemistry, Geophysics, Geosystems, 11, Q08003.

Hedrich S., Schlömann M. \& Johnson D.B. (2011) The iron-oxidizing proteobacteria. Microbiology, 157, 1551-1564.

Hopf J., Langerhorst F., Pollok K., Merten D. \& Kothe E. (2009) Influence of microorganisms on biotite dissolution: An experimental approach. Chemie der Erde Geochemistry, 69(S2), 45-56.

Huggett J. \& Cuadros J. (2005) Low-temperature illitization of smectite in the late Eocene and early Oligocene of the Isle of Wight (Hampshire basin), UK. American Mineralogist, 90, 1192-1202.

Huggett J. \& Cuadros J. (2010) Glauconite formation in lacustrine/palaeosol sediments, Isle of Wight (Hampshire basin), UK. Clay Minerals, 45, 35-49.

Huggett J., McCarty D., Calvert C., Gale A. \& Kirk C. (2006) Serpentine-nontronite-vermiculite mixed-layer clay from the Weches Formation, Claiborne Group, Middle Eocene, Northeast Texas. Clays and Clay Minerals, 54, 101-115.

Jaisi D.P., Kukkadapu R.K., Eberl D.D. \& Dong H. (2005) Control of Fe(III) site occupancy on the rate and extent of microbial reduction of $\mathrm{Fe}(\mathrm{III})$ in nontronite. Geochimica et Cosmochimica Acta, 69, 5429-5440.

Kalinowski B. \& Schweda P. (1996) Kinetics of muscovite, phlogopite, and biotite dissolution and alteration at $\mathrm{pH}$ 1-4, room temperature. Geochimica et Cosmochimica Acta, 60, 367-385.

Kawano M. \& Tomita K. (2001) Microbial biomineralization in weathered volcanic ash deposit and formation of biogenic minerals by experimental incubation. American Mineralogist, 86, 400-410.

Kennedy M., Droser M., Mayer L.M., Pevear D. \& Mrofka D. (2006) Late Precambrian oxygenation; inception of the clay mineral factory. Science, 311, 1446-1449.

Kieft T.L. (2000) Size matters: Dwarf cells in soil and subsurface terrestrial environments. Pp. 19-46 in: Non-culturable Microorganisms in the Environment (R.R. Colwell \& D.J. Grimes, editors). ASM Press, Washington, D.C.

Konhauser K. \& Urrutia M. (1999) Bacterial clay authigenesis: a common biogeochemical process. Chemical Geology, 161, 399-413.

Konhauser K.O., Fyfe W.S., Ferris F.G. \& Beveridge T.J. (1993) Metal sorption and mineral precipitation by bacteria in two Amazonian river systems: Rio Solimoes and Rio Negro, Brazil. Geology, 21, 1103-1106.

Konhauser K., Schiffman P. \& Fisher Q. (2002) Microbial mediation of authigenic clays during hydrothermal alteration of basaltic tephra, Kilauea volcano. Geochemistry Geophysics Geosystems, 3, 1075.

Kuhn K.M., DuBois J.L. \& Maurice P.A. (2013) Strategies of aerobic microbial $\mathrm{Fe}$ acquisition from Fe-bearing montmorillonite clay. Geochimica et Cosmochimica Acta, 117, 191-202.

Landeweert R., Hoffland E., Finlay R.D., Kuyper T.W. \& van Breemen N. (2001) Linking plants to rocks: ectomycorrhizal fungi mobilize nutrients from minerals. Trends in Ecology \& Evolution, 16, 248-254.

Lawrence C., Harden J. \& Maher K. (2014) Modeling the influence of organic acids on soil weathering. Geochimica et Cosmochimica Acta, 139, 487-507.

Lenton T.M., Crouch M., Johnson M., Pires N. \& Dolan L. (2012) First plants cooled the Ordovician. Nature Geoscience, 5, 86-89.

Li Z., Liu L., Chen J. \& Teng H.H. (2016) Cellular dissolution at hypha- and spore-mineral interfaces revealing unrecognized mechanisms and scales of fungal weathering. Geology, G37561.1. 
Lian B., Wang B., Pan M., Liu C. \& Teng H.H. (2008) Microbial release of potassium from Kbearing minerals by thermophilic fungus Aspergillus fumigatus. Geochimica et Cosmochimica Acta, 72, 87-98.

Lücking R., Huhndorf S., Pfister D.H., Plata E.R. \& Lumbsch H.T. (2009) Fungi evolved right on track. Mycologia, 101, 810-822.

Luef B., Fakra S.C., Csencsits R., Wrighton K.C., Williams K.H., Wilkins M.J., Downing K.H., Long P.E., Comolli L.R. \& Banfield J.F. (2013) Ironreducing bacteria accumulate ferric oxyhydroxide nanoparticle aggregates that may support planktonic growth. The ISME Journal, 7, 338-350.

Lünsdorf H., Erb R.W., Abraham W.R. \& Timmis K.N. (2000) "Clay Hutches": a novel interaction between bacteria and clay minerals. Environmental Microbiology, 2, 161-168.

McCollom T.M. \& Seewald J.S. (2013) Serpentinites, hydrogen, and life. Elements, 9, 129-134.

Ménez B., Pasini V. \& Brunelli D. (2012) Life in the hydrated suboceanic mantle. Nature Geoscience, 5, 133-137.

Miller J.D. (1992) Fungi as contaminants in indoor air. Atmospheric Environment, 26, 2163-2172.

Monreal C.M. \& Kodama H. (1997) Influence of aggregate architecture and minerals on living habitats and soil organic matter. Canadian Journal of Soil Science, 77, 367-377.

Moore J., Lichtner P., White A. \& Brantley S. (2012) Using a reactive transport model to elucidate differences between laboratory and field dissolution rates in regolith. Geochimica et Cosmochimica Acta, 93, 235-261.

Morrison K., Bristow T. \& Kennedy M. (2013) The reduction of structural iron in ferruginous smectite via the amino acid cysteine: Implications for an electron shuttling compound. Geochimica et Cosmochimica Acta, 104, 152-163.

Müller B. (2009) Impact of the bacterium Pseudomonas fluorescens and its genetic derivatives on vermiculite: Effect on trace metals contents and clay mineralogical properties. Geoderma, 153, 94-103.

Nealson K. \& Popa R. (2005) Introduction and overview: what do we know for sure? American Journal of Science, 305, 449-466.

Neumann A., Petit S. \& Hofstetter T. (2011) Evaluation of redox-active iron sites in smectites using middle and near infrared spectroscopy. Geochimica et Cosmochimica Acta, 75, 2336-2355.

Ottow J.C.G. \& Von Klopotek A. (1969) Enzymatic reduction of iron oxide by fungi. Applied Microbiology, 18, 41-43.

Perdrial J.N., Warr L.N., Perdrial N., Lett M.-C. \& Elsass F. (2009) Interaction between smectite and bacteria: Implications for bentonite as backfill material in the disposal of nuclear waste. Chemical Geology, 264, 281-294.
Perez Rodriguez J.L., Carretero M.I. \& Maqueda C. (1989) Behaviour of sepiolite, vermiculite and montmorillonite as supports in anaerobic digesters. Applied Clay Science, 4, 69-82.

Pinzari F., Cuadros J., Napoli R., Canfora L. \& Baussà Bardají D. (2016) Routes of phlogopite weathering by three fungal strains. Fungal Biology, 120, 1582-1599.

Prescott L., Harley J. \& Klein D. (1999) Microbiology, 4th edition. McGrawHill, New York. http://www.mhhe. com/biosci/cellmicro/prescott/index.mhtml.

Quirk J., Leake J.R., Banwart S.A., Taylor L.L. \& Beerling D.J. (2014) Weathering by tree-root-associating fungi diminishes under simulated Cenozoic atmospheric $\mathrm{CO}_{2}$ decline. Biogeosciences, 11, 321-331.

Ransom B., Bennett R.H., Baerwald R., Hulbert M.H. \& Burkett P.J. (1999) In situ conditions and interactions between microbes and minerals in fine-grained marine sediments: A TEM microfabric perspective. American Mineralogist, 84, 183-192.

Richardson S.M. \& McSween H.Y. (1998) Geochemistry: Pathways and Processes. Prentice Hall, New Jersey, USA.

Robertson K., Gauvin R. \& Finch J. (2005) Application of charge contrast imaging in mineral characterization. Minerals Engineering, 18, 343-352.

Rothschild L.J. \& Mancinelli R. (2001) Life in extreme environments. Nature, 409, 1092-1101.

Sanchez-Navas A., Martin-Algarra A. \& Nieto F. (1998) Bacterially-mediated authigenesis of clays in phosphate stromatolites. Sedimentology, 45, 519-533.

Schopf J.W. (2006) The first billion years: When did life emerge? Elements, 2, 229-233.

Six J., Conant R.T., Paul E.A. \& Paustian K. (2002) Stabilization mechanisms of soil organic matter: implications for C-saturation of soils. Plant and Soil, 241, 155-176.

Small J. (1994) Fluid composition, mineralogy and morphological changes associated with the semctiteto-illite reaction: an experimental investigation of the effect of organic acid anions. Clay Minerals, 29, 539-554.

Song W., Ogawa N., Oguchi C.T., Hatta T. \& Matsukura, Y. (2007) Effect of Bacillus subtilis on granite weathering: A laboratory experiment. Catena, 70, 275-281.

Staudigel H., Chastain R.A., Yayanos A. \& Bourcier W. (1995) Biologically mediated dissolution of glass. Chemical Geology, 126, 147-154.

Staudigel, H., Furnes, H., McLoughlin, N., Banerjee N. R., Connell L.B. \& Templeton A. (2008) 3.5 billion years of glass bioalteration: Volcanic rocks as a basis for microbial life? Earth Science Reviews, 89, 156-176.

Tazaki K. (2005) Microbial formation of a halloysite-like mineral. Clays and Clay Minerals, 53, 224-233. 
Thompson I.A., Huber D.M., Guest C.A. \& Schulze D.G. (2005) Fungal manganese oxidation in a reduced soil. Environmental Microbiology, 7, 1480-1487.

Thorseth I., Furnes H. \& Heldal M. (1992) The importance of microbiological activity in the alteration of natural basaltic glass. Geochimica et Cosmochimica Acta, 56, 845-850.

Thorseth I.H., Furnes H. \& Tumyr O. (1995a) Textural and chemical effects of bacterial activity on basaltic glass: an experimental approach. Chemical Geology, 119, 139-160.

Thorseth I.H., Torsvik T., Furnes H. \& Muehlenbachs K. (1995b) Microbes play an important role in the alteration of oceanic crust. Chemical Geology, 126, 137-146.

Thorseth I.H., Pedersen R.B. \& Christie D.M. (2003) Microbial alteration of $0-30$-Ma seafloor and subseafloor basaltic glasses from the Australian Antarctic Discordance. Earth and Planetary Science Letters, 215, 237-247.

Todar K. (2016) Online Textbook of Bacteriology. http:// textbookofbacteriology.net/.

Ueshima M. \& Tazaki K. (2001) Possible role of microbial polysaccharides in nontronite formation. Clays and Clay Minerals, 49, 292-299.

Ullman W., Kirchman D., Welch S. \& Vandevivere P. (1996) Laboratory evidence for microbially mediated silicate mineral dissolution in nature. Chemical Geology, 132, 11-17.

Uroz S., Calvaruso C., Turpault M.P., Sarniguet A., De Boer W., Leveau J.H.J. \& Frey-Klett P. (2009) Efficient mineral weathering is a distinctive functional trait of the bacterial genus Collimonas. Soil Biology and Biochemistry, 41, 2178-2186.

Urrutia M. \& Beveridge T. (1995) Formation of shortrange ordered aluminosilicates in the presence of a bacterial surface (Bacillus subtilis) and organic ligands. Geoderma, 65, 149-165.

Valsami-Jones E. \& McEldowney S. (2000) Mineral dissolution by heterotrophic bacteria: principles and methodologies. Pp. 27-55 in: Environmental Mineralogy; Microbial Interactions, Anthropogenic Influences, Contaminated Land and Waste Management (J.D. Cotter-Howells, L.S. Campbell, E. Valsami-Jones \& M. Batchelder, editors). The Mineralogical Society Series, no. 9, Mineralogical Society, London.
Van Veen J.A. \& Kuikman P.J. (1990) Soil structural aspects of decomposition of organic matter by microorganisms. Biogeochemistry, 11, 213-233.

Vieira M.J. \& Melo L.F. (1995) Effect of clay particles on the behaviour of biofilms formed by Pseudomonas fluorescens. Water Science \& Technology, 32, 45-52.

Wei Z., Kierans M. \& Gadd G.M. (2012) A model sheet mineral system to study fungal bioweathering of mica. Geomicrobiology Journal, 29, 323-331.

Whitman W.B., Coleman D.C. \& Wiebe W.J. (1998) Prokaryotes: The unseen majority. Proceedings of the National Academy of Sciences of the USA, 95, 6578-6583.

Wierzchos J. \& Ascaso C. (1996) Morphological and chemical features of bioweathered granitic biotite induced by lichen activity. Clays and Clay Minerals, 44, 653-657.

Wilson M.J. \& Jones D. (1983) Lichen weathering of minerals: implications for pedogenesis. Pp. 5-12 in: Residual Deposits: Surface Related Weathering Processes and Materials (R.C.L. Wilson, editor). Geological Society Special Publication no. 11, Geological Society, London.

Xiao B., Lian B., Sun L. \& Shao W. (2012) Gene transcription response to weathering of K-bearing minerals by Aspergillus fumigatus. Chemical Geology, 306-307, 1-9.

Zhang G., Dong H., Kim J. \& Eberl D. (2007a) Microbial reduction of structural $\mathrm{Fe}^{3+}$ in nontronite by a thermophilic bacterium and its role in promoting the smectite to illite reaction. American Mineralogist, 92, 1411-1419.

Zhang G., Kim J., Dong H. \& Sommer A. (2007b) Microbial effects in promoting the smectite to illite reaction: Role of organic matter intercalated in the interlayer. American Mineralogist, 92, 1401-1410.

Zierenberg R., Adams M. \& Arp A. (2000) Life in extreme environments: Hydrothermal vents. Proceedings of the National Academy of Sciences, 97, 12961-12962.

Zysset M. \& Schindler P. (1996) The proton promoted dissolution kinetics of K-montmorillonite. Geochimica et Cosmochimica Acta, 60, 921-931. 